\title{
8. SITE 500: MIDDLE AMERICA TRENCH AXIS ${ }^{1}$
}

\author{
Shipboard Scientific Party ${ }^{2}$
}

\section{HOLE 500}

Date occupied: 18 June 1979

Date departed: 22 June 1979

Time on hole: $103.6 \mathrm{hr}$.

Position: $12^{\circ} 41.35^{\prime} \mathrm{N}$; $90^{\circ} 56.49^{\prime} \mathrm{W}$

Water depth (sea level; corrected m, echo sounding): 6094

Water depth (rig floor; corrected m, echo sounding): 6104

Bottom felt (m, drill pipe): 6123

Penetration (m): 165.5

Number of cores: 19

Total length of cored section (m): 165.5

Total core recovered $(\mathrm{m}): 73.28$

Core recovery $(\%): 44.2$

Oldest sediment cored:

Depth sub-bottom (m): 157

Nature: Chalk

Age: Early Miocene

Measured velocity $(\mathrm{km} / \mathrm{s})$ : None

Basement: Not reached

Principal results: We repeated the stratigraphic section cored at Hole 499 , but with continuous coring to igneous rock at a sub-bottom depth of 156.5 meters. Although drilled at the landward edge of the trench axis, the recovered sedimentary section shows no more evidence of deformation than do its counterparts at Sites 495 and 499.

\section{HOLE 500A}

Date occupied: 23 June 1979

Date departed: 23 June 1979

Time on hole: $10.3 \mathrm{hr}$.

\footnotetext{
${ }^{1}$ Aubouin, J., von Huene, R., et al., Init, Repts. DSDP, 67: Washington (U.S. Govt. Printing Office)

2 Roland von Huene (Co-Chief Scientist), U.S. Geological Survey, Menlo Park, California; Jean Aubouin (Co-Chief Scientist), Département de Géologie Structurale, Université Pierre et Marie Curie, Paris, France; Jacques Azéma, Département de Géologie Structurale, Université Pierre et Marie Curie, Paris, France; Grant Blackinton, Hawaii Institute of Geophysics, University of Hawaii, Honolulu, Hawaii; Jerry A. Carter, Hawaii Institute of GeoSea Drilling Project, Scripps Institution of Oceanography, La Jolla, California; Darrel S. Cowan, Department of Geological Sciences, University of Washington, Seattle Washington; Joseph A. Curiale, Department of Geology, University of Oklahoma, Norman, Oklahoma (present address: Union Oil Company of California, P.O. Box 76, Brea, Ca.); Carlos A. Dengo, Department of Geology and Center for Tectonophysics, Texas A\&M University, College Station, Texas: Richard W. Faas, Department of Geology, Lafayette College, Easton, Pennsylvania; William Harrison, Department of Geology, University f Oklahom, Norman, Oklahom; Reinhard Hesse, Lehrstuhl für Geologie, Technische Universität, Münich, Federal Republic of Germany, and Department of Geological Sciences, McGill University, Montreal, Quebec, Canada; Donald M. Hussong, Hawaii Institute of Geophysics, University of Hawaii, Honolulu, Hawaii; John W. Ladd, The University of Texas, Marine Science Institute, Galveston, Texas (present address: Lamont-Doherty Geological Observatory, Palisades, New York); Nikita Muzylöy, Geological Institute, U.S.S.R. Academy of Sciences, Moscow, U.S.S.R versity, Kyoto, Japan; Peter R. Thompson, Lamont-Doherty Geological Observatory, Palisades, New York; and Jean Westberg, Geological Research Division, Scripps Institution of Oceanography, La Jolla, California.
}

Position: $12^{\circ} 41.16^{\prime} \mathrm{N} ; 90^{\circ} 56.58^{\prime} \mathrm{W}$

Water depth (sea level; corrected m, echo sounding): 6090

Water depth (rig floor; corrected $\mathrm{m}$, echo sounding): 6100

Bottom felt (m, drill pipe): 6127

Penetration (m): 120.0

Number of cores: 2

Total length of cored section (m): 15.0

Total core recovered $(\mathrm{m}): 8.07$

Core recovery $(\%): 53.8$

Oldest sediment cored:

Depth sub-bottom (m): 120

Nature: Diatomaceous mud and drill breccia

Age: Quaternary

Basement: Not reached

\section{HOLE 500B}

Date occupied: 23 June 1979

Date departed: 23 June 1979

Time on hole: $8.7 \mathrm{hr}$.

Position: $12^{\circ} 40.95^{\prime} \mathrm{N} ; 90^{\circ} 56.62^{\prime} \mathrm{W}$

Water depth (sea level; corrected m, echo sounding): 6090

Water depth (rig floor; corrected $\mathrm{m}$, echo sounding): 6100

Bottom felt (m, drill pipe): 6127

Penetration (m): 133.5

Number of cores: 3

Total length of cored section $(\mathrm{m}): \mathbf{2 8 . 5}$

Total core recovered $(\mathrm{m}): 16.75$

Core recovery $(\%): 59$

Oldest sediment cored:

Depth sub-bottom (m): 115

Nature: Diatomaceous mud and drill breccia

Age: Quaternary

Basement: Not reached

Principal results (Holes 500-500B): Site 500 is located at the juncture of the Guatemala slope and the Middle America Trench floor (Fig. 1). Lithologies and ages are basically the same as at Sites 499 and 495 , but the trench fill contains biogenic debris, including wood fragments that are more characteristic of the slope deposits at Site 494 than the turbidites at Site 499 . In Hole 500, the sequence of Quaternary trench-filling turbidite is either faulted or deposited against a fault scarp in lower Miocene chalk; basalt is at 161 meters. At Holes 500A and 500B, near the center of the Trench (Fig. 2), the trench-fill turbidites are thicker. Hard, undrillable zones of coarse basalt and sandstone cobbles were encountered at 114 and 125 meters sub-bottom depth in Holes 500A and 500B.

The bedding in both turbidite and chalk units is nearly horizontal. The chalk preserves structure best and shows rare, small (less than 5-cm displacement) reverse faults and a well-developed slickensided normal fault. Some of the small reverse faults appear to be 


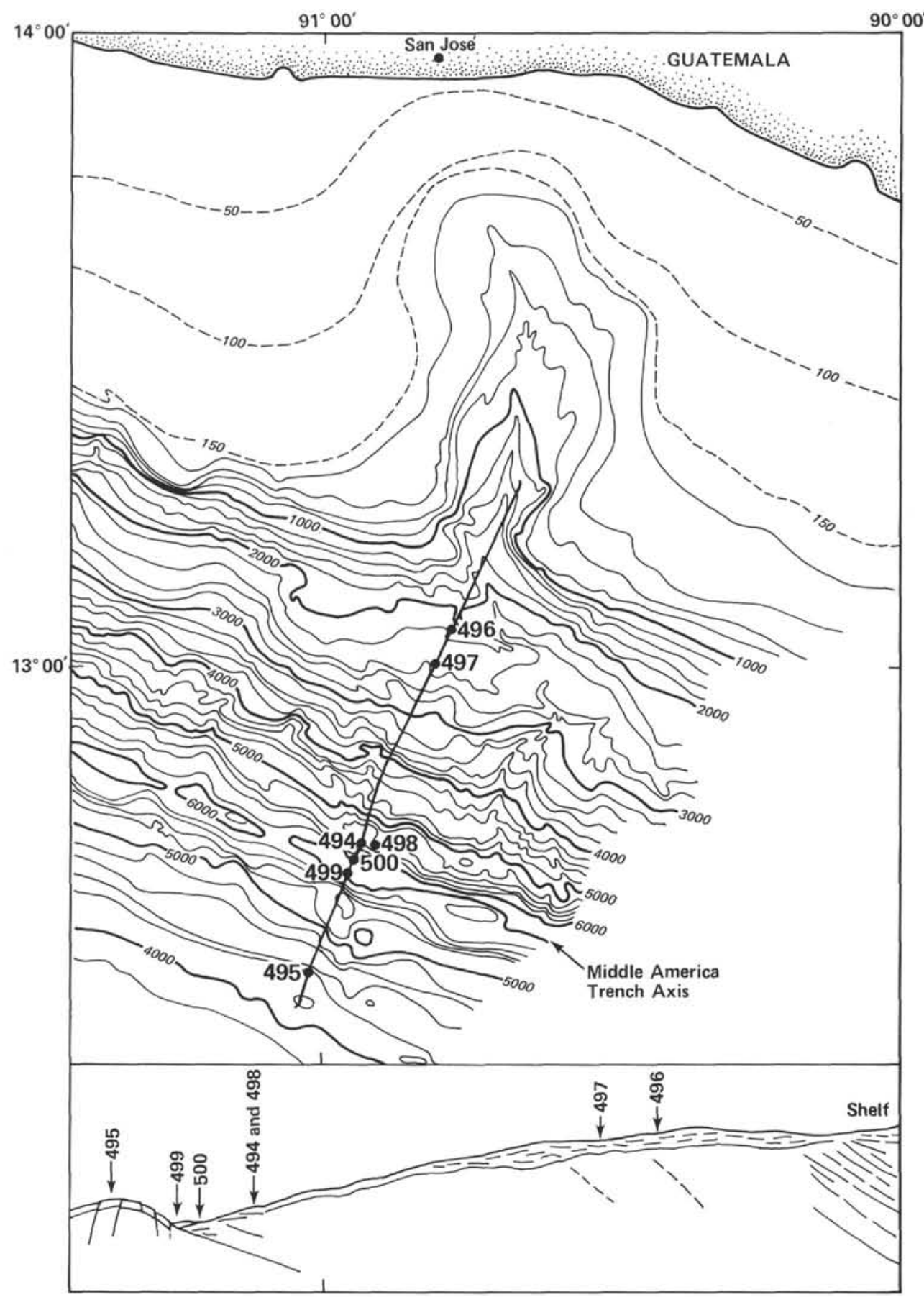

Figure 1. Location map and cross section showing the position of Site 500 .

caused by synsedimentary deformation; they are about as numerous as their counterparts in cores from Site 495.

The cores from Site 500 show no more deformation than their equivalents at Sites 499 and 495 . Between turbidite and chalk, a large fault cuts out at least 100 meters of section. It is interpreted to be a normal or strike-slip, for given right-side up, horizontal bedding, young rock cannot be placed over old rock and reduce the thickness of the section at the same time by reverse faulting. This interpretation is supported by the results of a Seabeam bathymetric survey that indicates continuity with a normal fault on the trench seaward slope. Furthermore, in this brittle and easily deformed chalk, compressional deformation is essentially absent.

Physical properties of the section at Site 500 are the same as those at Sites 499 and 495 . The first 80 meters are underconsoli- dated, and the last 40 meters are normal or slightly overconsolidated, a pattern common in the sites drilled on the Cocos Plate.

The composition of gaseous hydrocarbons is much as would be expected in a trench. Ethane values are low, and most of the gas is methane. The presence of pyrite and $\mathrm{H}_{2} \mathrm{~S}$, even in some cores of the chalk, indicates that anoxic conditions exist in the Trench.

\section{BACKGROUND AND OBJECTIVES}

Site 500, in the Middle America Trench off Guatemala, is at the juncture of the trench landward slope and the trench floor. It is at a depth slightly greater than 6100 meters. 


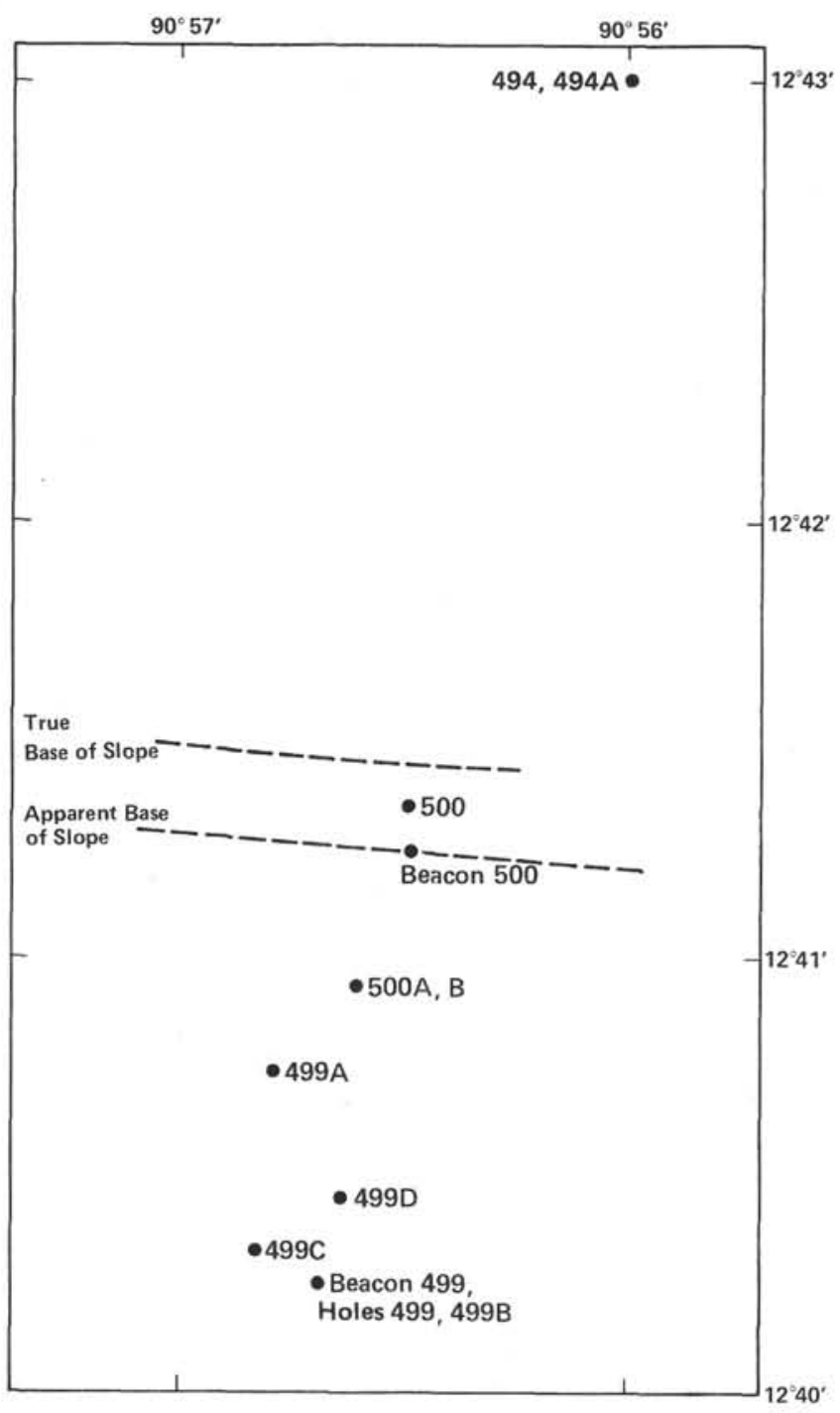

Figure 2. Location map details for holes drilled in the axis of the Middle America Trench.

Seismic records show the trench floor to be $3.1 \mathrm{~km}$ wide and a sequence of horizontal reflections underlain by gently landward-dipping reflections. At Site 499, the horizontal reflections correspond to Quaternary ponded, trench-filling turbidites, and the dipping reflections below correspond to the oceanic section drilled at Site 495 . The precise juncture of the trench floor and landward wall is obscured by diffractions.

Recovery of the trench fill and underlying section at this location would enable us to: (1) establish the lithology and age of the trench section that appears to continue beneath the slope and that may be drilled at Site 494; (2) analyze the development of the trench fill in space and time in conjunction with the drilling at Site 499; (3) compare the lithology and sedimentary structure of the trench fill to that of the slope apron; and (4) search for any deformation as the trench sediment enters the subduction zone.

The DSDP hydraulic piston corer (HPC) is capable of recovering undisturbed, oriented core, but it did not function properly; therefore the holes at Site 500 were rotary drilled.

\section{OPERATIONS}

The beacon for Site 500 was dropped using the Site 499 beacon as a reference. The new beacon was placed exactly at the intersection of the diffraction from the trench landward slope, with the horizontal reflector representing the trench floor. The desired hole position is 1200 feet landward of this intersection, within the "shadow" of the diffraction. The $16-\mathrm{kHz}$ beacon at Site 494, although already 27 days old, was still emitting a signal strong enough to interfere with a beacon of the same frequency dropped at Site 500 . Therefore, the site was positioned approximately where the diffraction and the trench floor intersect, slightly seaward of the optimal location.

The beacon drop at 1436L (Local Time), 18 June was followed by deployment of the hydraulic piston corer (HPC) assembly. Because of wear on rubber seals at the top of the HPC, sand-line trips had to be run at one-half normal speed. Most of 19 June was spent rigging and testing the oriented HPC device in deep water. Beginning late on the 19th, malfunction suggested that something had jammed the bit; therefore the string was pulled from the hole without recovery of sediment. Subsequently, the piston was found to have unscrewed and to have bridged the center opening of the bit by landing crossways in the lower cavity of the bit. The number of seals remaining allowed only three piston coring attempts; therefore we decided to return to rotary coring methods. The conventional drill string was started down at 1100 June 20 , and at 2300 the first water core was pulled. Spudding occurred at 0230 June 21 , and continuous coring proceeded until 2210 , June 22 , when igneous rock was encountered at an unexpectedly shallow depth in Hole 500 (Table 1). Hole 500A, a 2400 -ft. offset, was an attempt to establish basement depth near the middle of the trench, but a rubbly layer at about 115 meters caused sticking of the drill. The drill stem was pulled to mud line and Hole 500B washed to 105 meters and cored to 133.5 meters. At that depth a hard, rubbly layer again caused us to abandon the hole. Because a major objective was to $\log$ the trench section, at about $1600 \mathrm{~L}$ on 23 June, the ship, with drill string out but above the seafloor, was moved the maximum allowable distance toward the beacon at Site 499. Hole 499D was then penetrated to a sub-bottom depth of 216 meters in an attempt to obtain a log of a reasonable depth of section. Hard substrate was hit at 212 meters sub-bottom depth, and basalt was cored at 213 meters. Logging operations began at about $0300 \mathrm{~L}, 24$ June, but unfavorable hole conditions did not permit successful logging.

\section{LITHOSTRATIGRAPHY}

Glomar Challenger drilled at Site 500 to allow us to compare lithostratigraphic sections with Site 499. Drilling at both sites reached basalt, but sections recovered from offsets at each location (Fig. 2) indicate a complicated structure for the axis of the Middle America Trench. Seismic-reflection records show little topo- 
Table 1. Coring summary for Holes $500,500 \mathrm{~A}$, and 500B.

\begin{tabular}{|c|c|c|c|c|c|c|c|}
\hline Core No. & $\begin{array}{c}\text { Date } \\
\text { (June, 1979) }\end{array}$ & $\begin{array}{l}\text { Local Time } \\
\text { (L) }\end{array}$ & $\begin{array}{l}\text { Depth from } \\
\text { Drill Floor } \\
\text { (m; top-bottom) }\end{array}$ & $\begin{array}{c}\text { Sub-bottom } \\
\text { Depth } \\
\text { (m; top-bottom) }\end{array}$ & $\begin{array}{l}\text { Length } \\
\text { Cored } \\
\text { (m) }\end{array}$ & $\begin{array}{l}\text { Length } \\
\text { Recovered } \\
\text { (m) }\end{array}$ & $\begin{array}{c}\text { Recovery } \\
\left(\sigma_{0}\right)\end{array}$ \\
\hline \multicolumn{8}{|l|}{ Hole 500} \\
\hline 1 & 21 & 0328 & $6123.0-6127.5$ & $0.0-4.5$ & 4.5 & 3.25 & 72 \\
\hline 2 & 21 & 0504 & $6127.5-6137.0$ & $4.5-14.0$ & 9.5 & 2.63 & 27 \\
\hline 3 & 21 & 0644 & $6137,0-6146.5$ & $14.0-23.5$ & 9.5 & 5.00 & 53 \\
\hline 4 & 21 & 0844 & $6146.5-6156.0$ & $23.5-33.0$ & 9.5 & 5.28 & 56 \\
\hline 5 & 21 & 1012 & $6156.0-6165.5$ & $33.0-42.5$ & 9.5 & 2.01 & 21 \\
\hline 6 & 21 & 1142 & $6165.5-6175.0$ & $42.5-52.0$ & 9.5 & 0.0 & 0 \\
\hline 7 & 21 & 1348 & $6175.0-6184.5$ & $52.0-61.5$ & 9.5 & 7.70 & 81 \\
\hline 8 & 21 & 1836 & $6184.5-6194.0$ & $61.5-71.0$ & 9.5 & 1.11 & 12 \\
\hline 9 & 21 & 2044 & $6194.0-6203.5$ & $71.0-80.5$ & 9.5 & 8.60 & 90 \\
\hline 10 & 21 & 2242 & $6203.5-6213.0$ & $80.5-90.0$ & 9.5 & 4.85 & 51 \\
\hline 11 & 22 & 0037 & $6213.0-6222.5$ & $90.0-99.5$ & 9.5 & 2.47 & 26 \\
\hline 12 & 22 & 0215 & $6222.5-6232.0$ & $99.5-109.0$ & 9.5 & 4.30 & 45 \\
\hline 13 & 22 & 0345 & $6232.0-6241.5$ & $109.0-118.5$ & 9.5 & 4.44 & 47 \\
\hline 14 & 22 & 0932 & $6241.5-6251.0$ & $118.5-128.0$ & 9.5 & 5.14 & 54 \\
\hline 15 & 22 & 1105 & $6251.0-6260.5$ & $128.0-137.5$ & 9.5 & 7.31 & 77 \\
\hline 16 & 22 & 1300 & $6260.5-6270.0$ & $137.5-147.0$ & 9.5 & 1.03 & 11 \\
\hline 17 & 22 & 1446 & $6270.0-6279.5$ & $147.0-156.5$ & 9.5 & 7.23 & 76 \\
\hline 18 & 22 & 1658 & $6279.5-6281.5$ & $156.5-158.5$ & 2.0 & 0.40 & 20 \\
\hline 19 & 22 & 2050 & $6281.5-6288.5$ & $158.5-165.5$ & 7.0 & 0.53 & 7 \\
\hline \multicolumn{8}{|l|}{ Hole $500 \mathrm{~A}$} \\
\hline 1 & 23 & 0413 & $6222.5-6232.0$ & $95.5-105.0$ & 9.5 & 7.85 & 83 \\
\hline 2 & 23 & 0708 & $6241.5-6247.0$ & $114.5-120.0$ & 5.5 & 0.22 & 4 \\
\hline \multicolumn{8}{|l|}{ Hole $500 \mathrm{~B}$} \\
\hline $\mathrm{H} 1$ & 23 & 1045 & $6127.0-6232.0$ & $0.0-105.0$ & Wash & 1.62 & \\
\hline 1 & 23 & 1220 & $6232,0-6241.5$ & $105.0-114.5$ & 9.5 & 7.96 & 84 \\
\hline 2 & 23 & 1405 & $6241.5-6251.0$ & $114.5-124.0$ & 9.5 & 8.01 & 84 \\
\hline 3 & 23 & 1606 & $6251.0-6260.5$ & $124,0-133.5$ & 9.5 & 0.78 & 8 \\
\hline
\end{tabular}

graphic detail for depths as great as those of the trench axis, and reflections from sub-bottom features are obscured by both diffractions and side echoes. Interpretations of geologic structure based on comparisons of lithologic sections from the eight holes drilled in the Middle America Trench axis, therefore, are not related to geophysical data.

Broadly described, the lithologic section at Site 500 consists of five units: turbidites, diatomaceous muds, foraminifer-nannofossil chalk, and basalt-the calcareous sequence of Site 499 was split into two units, accordingly, a similar division is made for Site 500 (Fig. 3).

\section{Sediments}

Unit 1 (Hole 500, Core 1 to Core 10, Section 2, 0-82 m sub-bottom depth; Quaternary)

Dark olive gray (5Y 3/2) turbidites compose this unit. These sediments are gassy and strongly deformed by drilling; sand layers are common. Recovery was poor in Core 8 , and there was no recovery for Core 6 . The lost layers are most likely to have been sandy. Cores 7,8 , and 9 include up to $30 \%$ volcanic glass.

\section{Unit 2 (Hole 500A, Core 1, 95.5-105 m sub-bottom depth; Hole 500B, Cores 1 to 3, 105-124.5 m sub-bottom depth; Quaternary)}

The dark olive gray (5Y $3 / 2$ ), diatomaceous, hemipelagic mud of this unit corresponds to the lithology of Unit 1 of Site 495 and Unit 2 of Site 499. Both Holes $500 \mathrm{~A}$ and $500 \mathrm{~B}$ were washed to the level of this sediment; therefore the contact with overlying turbidites (Unit 1 of Hole 500) was not observed. Sediment of Unit 2 is distinguished from that of Unit 1 by the absence of sand layers. Because coarse-grained sand is present just above the contact with foraminifer-nannofossil ooze of Unit 3, the hemipelagic muds of Unit 2 must be missing at Hole 500 , the only hole continuously cored at Site 500 (Fig. 3). Cobbles of weathered basalt underlie Unit 2 at both Holes 500A and 500B and occur within Cores 1 and 2 of Hole 500B.

\section{Unit 3 (Hole 500, Core 10, Section 2-Core 16, 82-147 m sub-bottom depth; lower Miocene)}

Unit 3 is a white to pale blue white foraminifer-nannofossil chalk. Munsell codes do not adequately describe the subtle coloring of this rock. Drilling disturbed the contact with overlying turbidites so that clasts of the two units have been mechanically worked into each other. The chalk is very faintly mottled, suggesting bioturbation, but laminations are well preserved in Core 13, Section 2. Drilling brecciated sections of Cores 11, 13,15 , and 16 and fragments of banded chert were recovered in the latter two cores. A gel-like substance (early diagenetic phase of chert?) was recovered in Core 15; the chalk, described as Unit 3 at Hole 500, probably corresponds to the lower part of Unit 4, Hole 499B.

\section{Unit 4 (Hole 500, Core 17, 147-156.5 m sub-bottom depth; lower Miocene)}

Corresponding to Unit 5 of Hole 499B, this unit consists of pale yellow, nannofossil chalks characterized by dendritic manganese precipitates; both units immediately overlie basalt.

\section{Unit 5 (Hole 500, Cores 18 and 19, 156.5-165.5 m sub-bottom depth)}

This unit comprises basement rock; these basalts are described in a following section.

\section{Discussion}

Lithologies occur at different levels in the eight holes drilled in the Middle America Trench axis (Fig. 4). Diatomaceous, hemipelagic muds are absent at Hole 500 . 


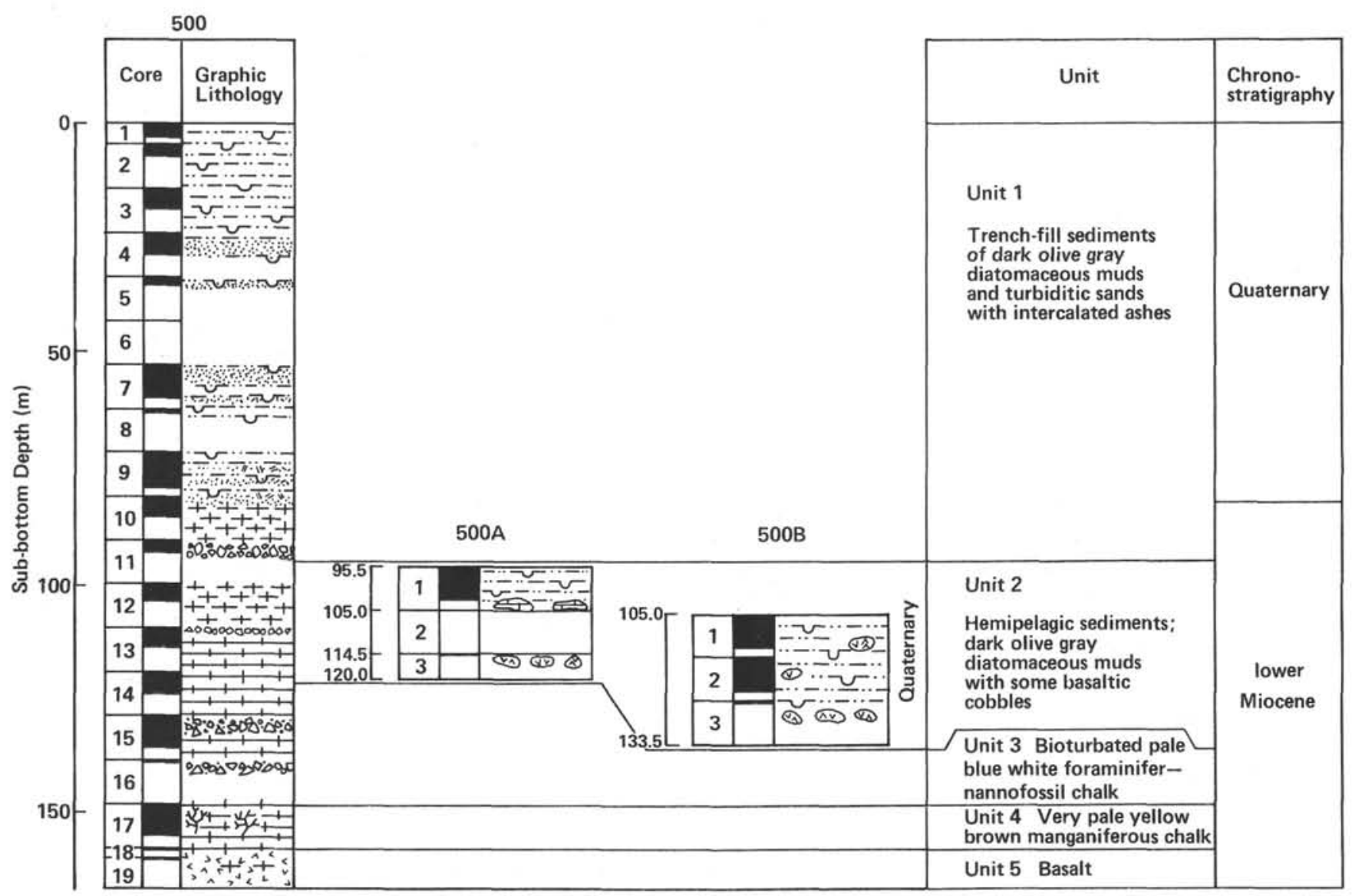

Figure 3. Summary lithologic column for Site 500. (Symbols follow DSDP format.)

Turbidites at Hole 500 are thinner than their counterparts at Hole 499, and, as mentioned in the description of Unit 3, part of the uppermost nannofossil chalk at Hole 500 seems to be missing. Basalt cobbles are present at relatively high levels within hemipelagic mud at Holes $500 \mathrm{~A}$ and 500B. Those weathered rocks appear to be part of a talus deposit and not the equivalent of the basement rocks reached in Holes 500, 499B, 499C, and 499D. There are no signs of folding or compressive structures at either Site 499 or Site 500 . These relationships and the hole locations (Fig. 2) suggest that normal faults offset the seaward slope of the Middle America Trench. Abbreviated sections, reworked cobbles, and varying thickness of lithologic units are explained by such a structural pattern. The upper surfaces of flexed, subducting, oceanic plates are thought to be in extension, because focal mechanism solutions indicate extension along the outer swells (ridges) of trenches (Isacks and Molnar, 1971) and anastomosing networks of offsets have been mapped off Peru and Chile (Coulbourn, 1981) and off Guatemala (Aubouin et al., this volume). These lines of evidence and drilling at Sites 499 and 500 indicate that normal faults, although not the only structure possible, best explain the variability of lithologies in the Middle America Trench axis. Drilling at Sites 499 and 500, however, does not constrain interpretation of structures of the landward slope of the trench.

\section{Basalt}

Several pieces of fresh to slightly altered basalt were recovered in Hole 500, Cores 18 and 19, and Hole 500B, Core 3. The basalt ranges from aphyric to microphyric. Both varieties have a microlitic dark gray groundmass; the microphyric specimens typically contain $1 \%$ to $3 \%$ plagioclase laths (up to $3 \mathrm{~mm}$ long) and $1 \%$ or less of olivine phenocrysts (less than $1 \mathrm{~mm}$ in diameter) that are generally altered to greenish or orange brown clay. A few pieces have localized, thin selvages of chalk, drusy calcite, or green clay. Many fragments have partial or complete, pale brown weathering rinds, which extend several millimeters inward from the surface and surround fresher, dark gray cores. Piece 4 in Core 19 has a partial selvage of hard, probably baked, creamy white chalk containing a few fragments of tan basalt and soft, green clay. Relict tests of foraminifers are visible with a hand lens. In thin section, the chalk is mainly recrystallized micrite containing patches of sparry calcite, some of which replaced foraminifer tests. The chalk, which was probably originally similar to the nannofossil ooze overlying oceanic basement, is in sharp contact with basalt.

Petrographic analysis of a representative sample of fresh basalt (Core 18, Piece 1) shows that it consists of about $60 \%$ zoned plagioclase microlites $0.3 \mathrm{~mm}$ long 


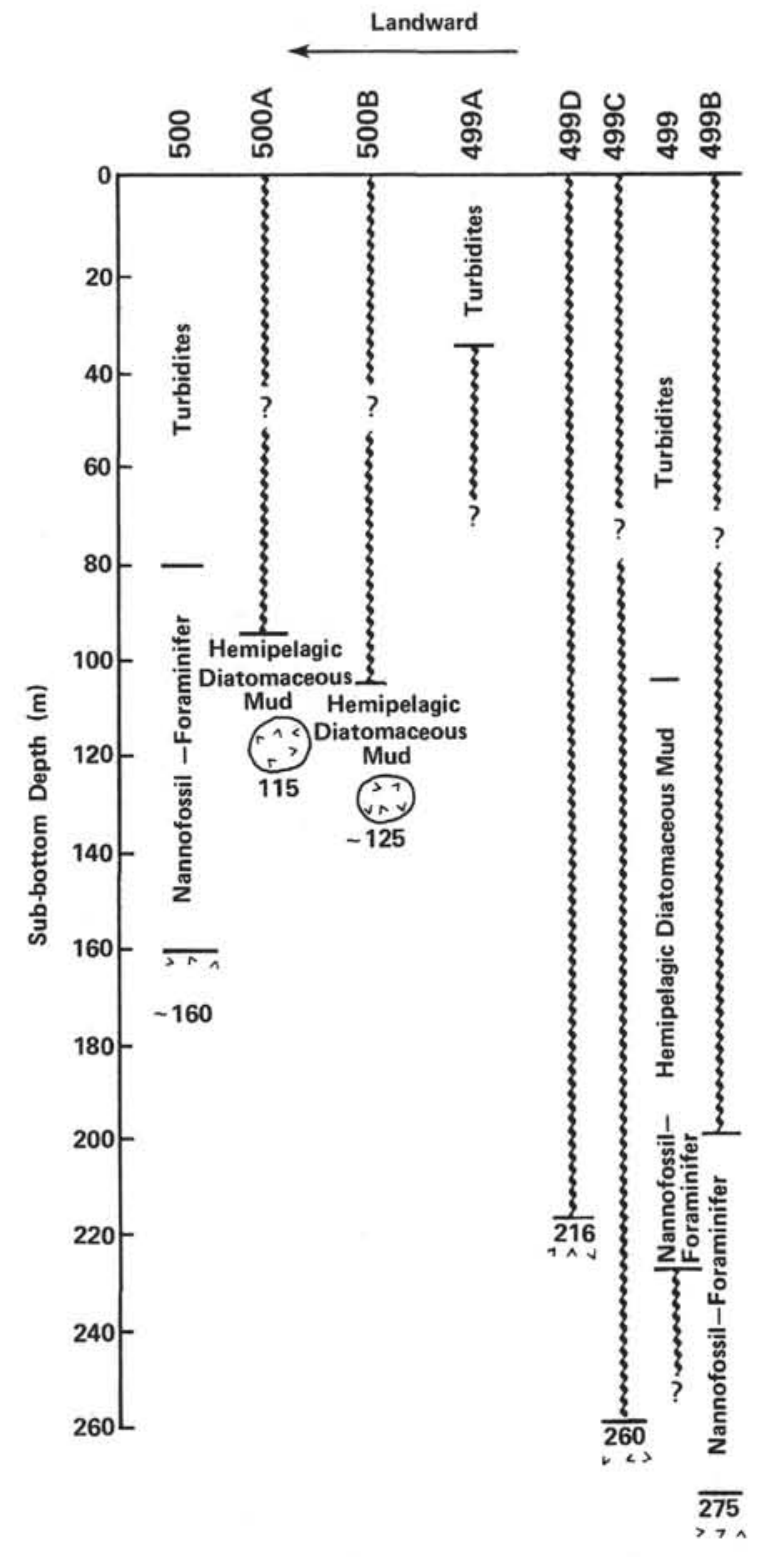

Figure 4. Comparison of lithologic units at Sites 499 and 500.

and $40 \%$ intergranular clinopyroxene, which crystallized in finely fibrous and plumose aggregates between feldspar grains. This sample also contains $2 \%$ subhedral olivine grains, $0.2 \mathrm{~mm}$ in diameter, which are partly altered to clay. The conspicuous brown altered zones are apparently the result of widespread replacement of clinopyroxene by orange brown clay minerals. In Hole $500 \mathrm{~B}$, Core 3 , very fine grains of unoxidized pyrite average $1 \%$ to $2 \%$ of most samples. This suite of alteration minerals-clay, calcite, pyrite-indicates low-temperature interactions of seawater and basalt.

Cores 18 and 19 in Hole 500 probably sampled a complex zone at the contact of oceanic basement with overlying nannofossiliferous sediments. A few of the basalt pieces have smooth surfaces, subrounded shapes, and complete weathering rinds, which indicate that they existed in situ as pebbles or clasts. Other pieces have clearly been "drilled out of" flows or fragments of flows that have a larger diameter than the drill string.
The nannofossiliferous, foraminiferal chalk adhering to some recovered pieces is probably seafloor sediment baked and enclosed by irregularly flowing basalt as it extruded. Or is it part of a thin chalk layer between two flows? Similar chalk-cemented breccias and interpillow sediments have been recovered in the Atlantic Ocean on Legs 45,46 , and 49.

\section{PHYSICAL PROPERTIES}

\section{Bulk Density and Water Content}

Plots of the distribution of bulk density and water content with depth reflects the stratigraphy particularly well (Fig. 5). Bulk density fluctuates through the turbidite section (Unit 1), which extends from the mud line down to 90 meters (Core 10, Section 2). These fluctuations are followed by a sharp increase in bulk density at the contact with the foraminifer-nannofossil ooze, and values remain constant to 127 meters (Unit 2). Bulk density again increases abruptly in the foraminifer-nannofossil chalk and remains relatively constant at $1.75 \mathrm{Mg}$ / $\mathrm{m}^{3}$ to the basalt at 168 meters (Unit 3).

Because water content normally varies inversely with bulk density, it would also be expected to show discontinuities at lithologic breaks. The reverse situation occurs between 90 and 127 meters, however. The entire foraminifer-nannofossil ooze is water-rich, the water content varying directly with the bulk density. Fractures and fissures may have developed within this unit, allowing water to penetrate the rock; between adjacent fractures, however, the rock may have remained tightly compacted, still possessing its higher density.

Alternating lithologies, like turbidites, might produce the variability in bulk density throughout Unit 1 (Fig. 5 shows only core average values). However, the variability may also result from the considerable amount of gas generated within Unit 1 . Gas pockets and voids occur throughout the unit and affect the bulk density as determined by the GRAPE.

\section{Shear Strength}

\section{Hole 500}

Shear strength ranged from $1.91 \mathrm{kPa}$ to $23.94 \mathrm{kPa}$ (Fig. 6). The upper 80 meters of sediments showed the lowest values, averaging about $5 \mathrm{kPa}$ through the interval. This gassy zone clearly shows the effects of gas on shear strength. Strength increases linearly from 60 meters (Core 7) to its maximum at 117 meters (Core 13) at the base of the foraminifer-nannofossil ooze.

Table 2 presents a summary of the physical properties for Site 500 .

\section{Water Content and Shear Strength}

\section{Holes 500A and 500B}

Only one core was taken at Hole 500A, and only two cores at Hole 500B; hence, little useful information on physical properties was obtained. Table 2 presents the limited data from the cores.

Core 1 (Hole 500) shows the proper water content and shear strength values to be assigned to the lower 


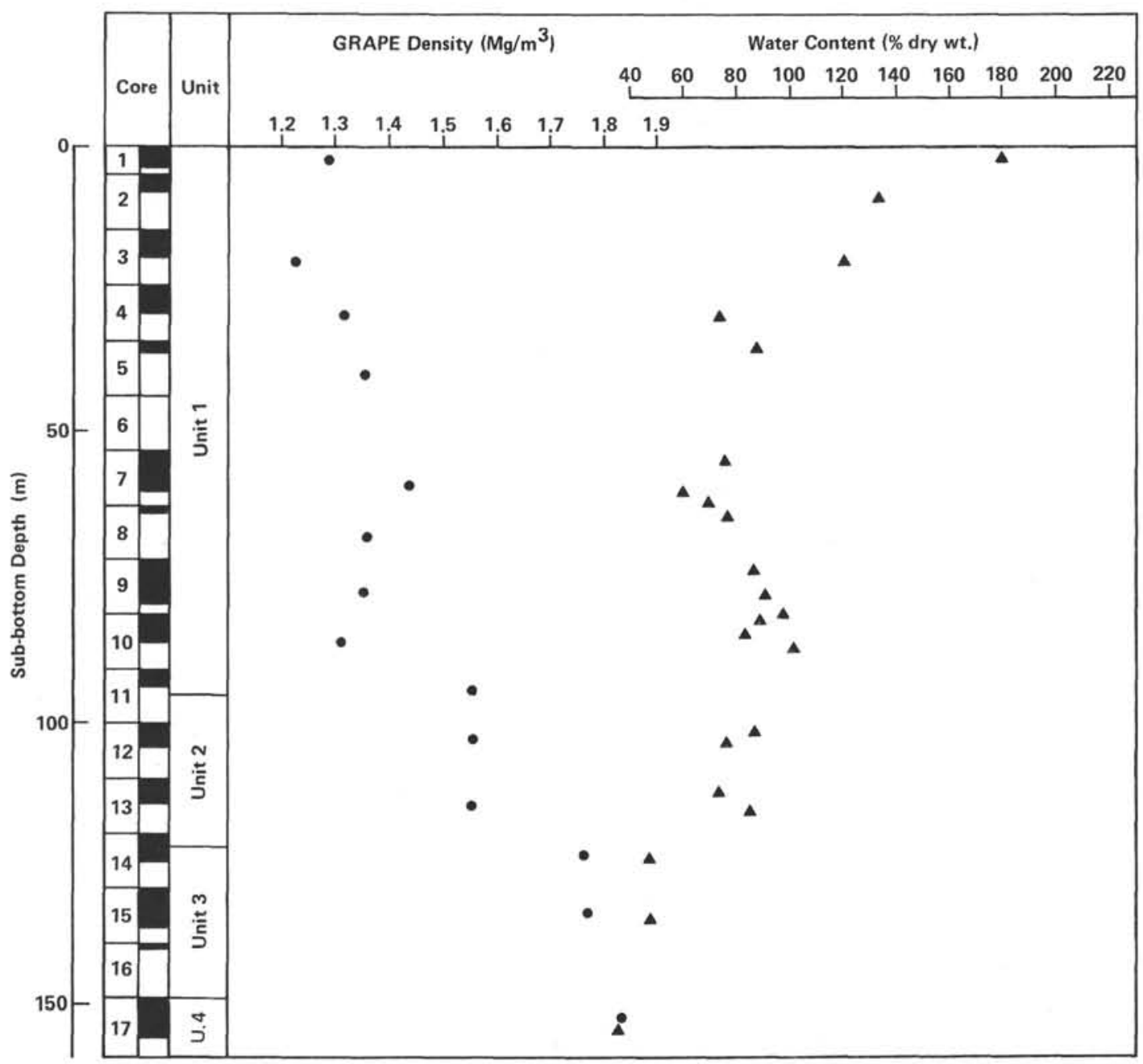

Figure 5. GRAPE density $(\bullet)$ and water content $(\mathbf{\Delta})$ at Hole 500.

part of Unit 1 (Fig. 5). In Hole 500, Unit 1 extends to 90 meters. In Hole 500A, Unit 1 would extend to at least 120 meters.

Cores 1 and 2 from Hole 500B pose somewhat of a problem. The water content of Core 1 (average 98.7\%) would assign it to Unit 1 (Fig. 5). However, shear strength averages $45.4 \mathrm{kPa}$, which is three to four times greater than the shear strength of Unit 1 sediments in Hole 500 (Fig. 5). Core 2 from Hole 500B presents an even greater problem. It is exceedingly water-rich (average $172.7 \%$ water content), possesses a high shear strength $(49.03 \mathrm{kPa})$, and is clearly lithologically dissimilar to Units 1, 2, or 3 at Hole 500. It contains fossils (radiolarians) identified as lower Quaternary. It cannot be easily assigned to a stratigraphic position with respect to Figure 5.

\section{GEOPHYSICS}

The holes at site 500 were drilled to sample sediments near the foot of the landward slope of the trench, a location where sediments might begin to deform as they are subducted beneath the trench landward slope. The position of the holes in the trench are indicated on Figures 1 and 2 .
The seismic section in Figure 7 shows numerous diffractions in the vicinity of Site 500. The trench fill seaward of Site 500 is indicated by horizontal reflections, below which are gentle, landward-dipping reflections that drilling at Site 499 showed to be oceanic pelagic and hemipelagic sediment. The landward dip of the oceanic sediments suggested to us that we would find a thicker section of turbidite fill at Site 500 then at Site 499 . However, in Hole 500 the trench fill is faulted against chalk, and basalt basement is at a sub-bottom depth of 156 meters, more than 100 meters shallower than at Site 499. This elevation puts basalt at about $0.2 \mathrm{~s}$ sub-bottom (assuming $V=1500 \mathrm{~m} / \mathrm{s}$ ) on the seismic section at the crest of a strong diffraction hyperbola. Because the oceanic hemipelagic section is missing at Site $500 \mathrm{com}$ pared to Site 499 , we think that Hole 500 cuts a normal fault. The broken diffraction pattern may be caused by a fault or faults that cut the section.

Holes 500A and 500B bottom in basalt and sandstone cobbles at 120 and 133 meters, respectively. These depths translate to about $0.15 \mathrm{~s}$ on the time section at a weak horizontal reflection. The seismic section of Figure 7 suggests that there is a layered sequence beneath the base of these holes. However, high-resolution records 


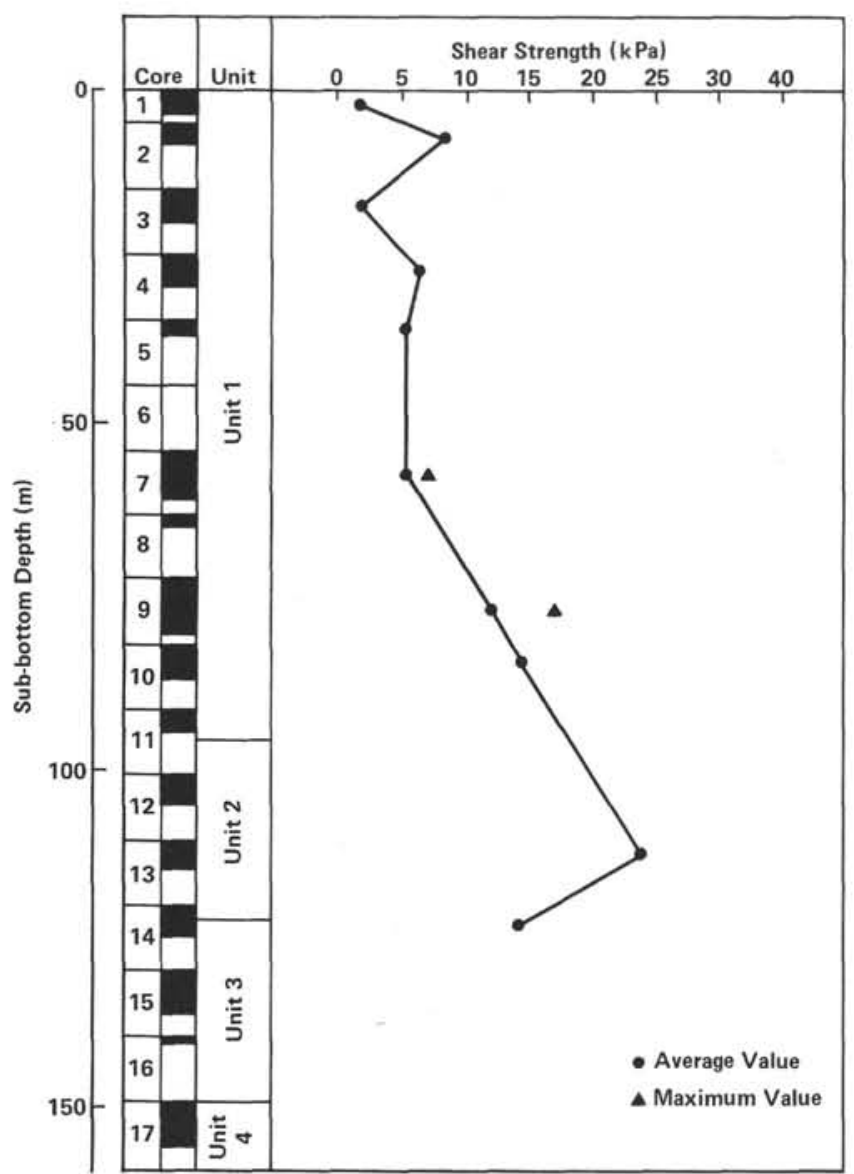

Figure 6. Shear strength profile at Hole 500.

Table 2. Physical properties, Site 500.

\begin{tabular}{|c|c|c|c|c|c|c|}
\hline $\begin{array}{c}\text { Sample } \\
\text { (core-section, } \\
\text { interval in cm) }\end{array}$ & $\begin{array}{c}\text { GRAPE } \\
\text { Wet-Bulk } \\
\text { Density } \\
\left(\mathrm{mg} / \mathrm{m}^{3}\right)\end{array}$ & $\begin{array}{l}\text { P.Wave } \\
\text { Velocity } \\
(\mathrm{km} / \mathrm{s})\end{array}$ & $\begin{array}{c}\text { Acoustic } \\
\text { Impedance } \\
\left(\times 10^{5} \mathrm{~g} / \mathrm{cm}^{2} \cdot \mathrm{s}\right)\end{array}$ & $\begin{array}{l}\text { Shear } \\
\text { Strength } \\
\text { (kPa) }\end{array}$ & $\begin{array}{c}\text { Water } \\
\text { Content } \\
\text { ( } \% \text { dry wt.) }\end{array}$ & $\begin{array}{l}\text { Porosity } \\
\text { (vol. \%) }\end{array}$ \\
\hline \multicolumn{7}{|l|}{ Hole 500} \\
\hline $1-1,0-1$ & - & - & - & - & 224.27 & 84.98 \\
\hline $1-1,100-102$ & - & - & - & 1.91 & 177.67 & 81.70 \\
\hline $2-1,86-88$ & - & - & - & 8.62 & 133.79 & 77.15 \\
\hline $3-2,130-132$ & - & - & - & 2.29 & 120.16 & 75.14 \\
\hline $3-6,10-12$ & - & - & - & 6.70 & - & - \\
\hline $4-2,66-68$ & 1.47 & - & - & 6.12 & 77.32 & 66.05 \\
\hline $5-2,19-20$ & 1.46 & - & - & 5.88 & 86.55 & 68.59 \\
\hline $7-1,68-70$ & - & - & - & 7.27 & 75.67 & 65.53 \\
\hline $7-5,108-110$ & 1.45 & - & - & 4.90 & 59.42 & 59.90 \\
\hline $7-8,21-23$ & - & - & - & - & 67.54 & 63.04 \\
\hline $8-1,29-31$ & 1.40 & - & - & - & 78.50 & 66.38 \\
\hline $9-3,140-142$ & - & - & - & 8.24 & 87.43 & 68.85 \\
\hline $9-5,143-145$ & - & - & - & 11.77 & 92.25 & 70.02 \\
\hline $9-7,96-98$ & - & - & - & 17.06 & 97.25 & 71.03 \\
\hline $10-1,110-112$ & - & - & - & - & 90.03 & 69.38 \\
\hline $10-3,3-5$ & 1.55 & - & - & 14.36 & 80.91 & 67.07 \\
\hline $12-1,140-142$ & 1.55 & - & - & - & 86,95 & 69.39 \\
\hline $12-2,140-142$ & 1.65 & - & - & - & 77.79 & 66.23 \\
\hline $13-2,9-11$ & 1.66 & 1.528 & 1.59 & - & - & - \\
\hline $13-2,42-44$ & 1.66 & - & - & 23.94 & 62.82 & 61.36 \\
\hline $13-3,110-112$ & 1.65 & - & - & - & 84.47 & 68.01 \\
\hline $14-1,19-21$ & 1.65 & 1.744 & 2.88 & - & - & - \\
\hline $14-2,77-79$ & - & - & - & 14.36 & 47.30 & 54.43 \\
\hline $15-4,38-40$ & 1.80 & 1.885 & - & - & 47.80 & 54.75 \\
\hline $17-2,89-91$ & 1.90 & 2.477 & 4.70 & - & - & - \\
\hline $17-3,49-51$ & 1.90 & 1.885 & 3.58 & - & - & - \\
\hline $17-3,51-53$ & 1.90 & - & - & - & 34.42 & 46.38 \\
\hline \multicolumn{7}{|l|}{ Hole $500 \mathrm{~A}$} \\
\hline $1-1.72-74$ & - & - & - & - & 108.6 & 73.2 \\
\hline $1-1,120-122$ & - & - & - & 13.60 & - & - \\
\hline $1-3,58-60$ & - & - & - & 7.85 & - & - \\
\hline $1-3,68-70$ & - & - & - & - & 115.6 & 74.1 \\
\hline \multicolumn{7}{|l|}{ Hole $500 \mathrm{~B}$} \\
\hline $1-1,81-84$ & - & - & - & 33.52 & 93.4 & 70.3 \\
\hline $1-4,122-124$ & - & - & - & 47.88 & 99.1 & 71.4 \\
\hline $1-6.50-52$ & - & - & - & 51.71 & 103.6 & 72.3 \\
\hline $2 \cdot 2,50-52$ & - & - & - & 67.03 & 166.4 & 80.8 \\
\hline $2-5,63-65$ & - & - & - & 28.73 & 178.9 & 81.8 \\
\hline
\end{tabular}

are required to achieve a scale small enough to resolve the complex structure suggested by drill results from Sites 499 and 500. Our drilling results and Seabeam bathymetry (Aubouin et al., this volume) indicate that the holes at Site 500 were drilled on the flanks of a horst that intersects the landward slope at an oblique angle.

\section{BIOSTRATIGRAPHY}

The three holes drilled at Site 500 penetrated Quaternary hemipelagic turbidites unconformably overlying lower Miocene chalks in contact with basalt (Fig. 8).

Microfossils from the Quaternary turbidites consist of planktonic foraminifers (moderately well-preserved, not very abundant); benthic foraminifers (well-preserved, often abundant); nannofossils (well-preserved, abundant); radiolarians (moderately well-preserved, common); plant debris; fecal pellets; fish bones, scales, and teeth; echinoid spines; otoliths (rare); mollusc fragments, and ostracodes. Concentrations of these biogenic remains are accompanied by coarse sand, indicating displacement from shallow water. Sedimentation rates for Hole 500 are summarized in Figure 9. Lower-slope taxa dominate benthic foraminiferal assemblages at all three sites, although elements from shallower depths occur.

In Hole 500, lower Miocene nannofossil chalk unconformably underlies the turbidites. The contact is abrupt between Sections 500-10-1 and 500-10-2, but clasts of the carbonate can be found up as far as Core 9 .

Chalks of the lower unit are rich in nannofossils and planktonic foraminifers; radiolarians occur down to the bottom of Core 14. Benthic foraminifers are characteristic of middle bathyal depths, about 2500 meters.

\section{Foraminifers}

At Site 500 upper Quaternary hemiterrigenous turbidites overlie lower Miocene nannofossil chalk. Both units bear foraminifers. The muddy, olive green turbidites were correlated by planktonic foraminifers to the upper part of the Neogloboquadrina eggeri assemblage zone. Characteristic species include N. eggeri, Globorotalia menardii, Globigerina glutinata, Globigerinoides ruber, and $G$. sacculifer. Benthic taxa such as Nonionella basispinata, Ammonia, and Elphidium indicate that the sediments were derived from the shelf; Angulogerina, Bolivina pacifica, B. spissa, and B. pseudobeyrichi are reworked from the upper bathyal zone; Valvulineria, Martinottiella, Globobulimina pacifica, Melonis salisburyi, and Uvigerina peregrina represent the middle or lower bathyal zone. These planktonic and benthic assemblages were observed in Hole 500, Core 1 through Core 10, Section 1; in Hole 500A, Cores 1 and 2; and Hole 500B, Cores 1 and 2.

The lower Miocene chalks ranged from the middle of Zone N7 to lower N4. The overlap of Orbulina suturalis and Globigerinatella insueta in Hole 500, Core 10, Section 2 provides an approximate age of $15.6 \mathrm{~m}$.y. for the top of the chalk. Disappearance of Catapsydrax dissimilis between Core 13, Section 2 and Core 12, Section 3 brackets the N6/N7 boundary at about $18 \mathrm{~m} . \mathrm{y}$.; and the extinction of Globorotalia kugleri between Core 15, Section 1 and Core 14, Section 1 defines the N4/N5 


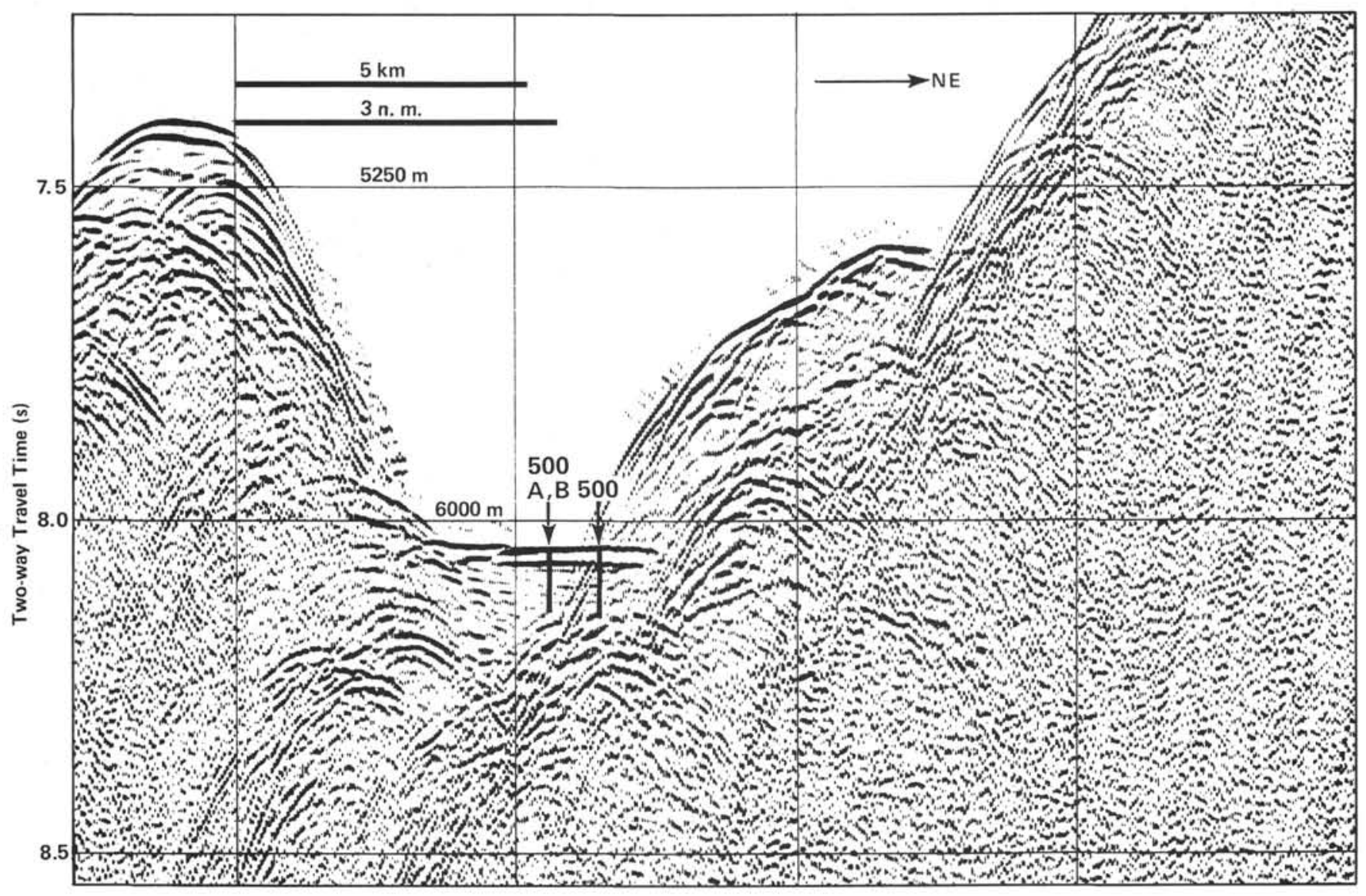

Figure 7. Seismic-reflection profile GUA-13 recorded across the Middle America Trench axis.

\begin{tabular}{|l|l|l|l|}
\hline Series & \multicolumn{1}{|c|}{$\begin{array}{c}\text { Sample } \\
\text { (hole-core-section, } \\
\text { interval in cm) }\end{array}$} & $\begin{array}{l}\text { Approximate } \\
\text { Sub-bottom } \\
\text { Depths of } \\
\text { Boundary }(\mathrm{m})\end{array}$ & Basis for Boundary Position \\
\hline Quaternary & $\begin{array}{l}500-1 \rightarrow-10-2,40 \mathrm{~cm} \text { and } \\
500 \mathrm{~A}-1 \rightarrow-2 \text { and } \\
500 \mathrm{~B}-1 \rightarrow-2\end{array}$ & 82.4 & $\begin{array}{l}\text { ?S. heteromorphus/ } \\
\text { H. ampliaperta Zones } \\
\text { N4 through N7 } \\
\text { S. delmontensis Zone through } \\
\text { D. alata Zone }\end{array}$ \\
\hline lower Miocene & $500-10-2,40 \mathrm{~cm} \rightarrow-17, \mathrm{CC}$ & 154 & \begin{tabular}{l} 
D. deflandrei Subzone \\
\hline Basalt
\end{tabular}
\end{tabular}

Figure 8. Stratigraphic series at Holes 500, 500A, and 500B.

boundary of 20.5 m.y. Globigerinoides primordius was present in the core catcher at Core 17, indicating that Hole 500 terminated within the lower Miocene.

\section{Radiolarians}

Sediments of Site 500 contain moderately well-preserved radiolarian assemblages ranging from lower Miocene to Quaternary. The siliceous muds and turbidites of Cores 500-1 through 500-10-2 and of Holes 500A and 500B contain Quaternary radiolarians.
A contact at Sample 500-10-2, $40 \mathrm{~cm}$, between lower Quaternary turbidites and foraminifer-nannofossil ooze, is drilling disturbed; but Sample 500-10-2, 127-129 cm included a pure radiolarian assemblage from the Dorcadospyris alata Zone of the lowest middle Miocene. This zone is also represented at Sample 500-10-3, 127$129 \mathrm{~cm}$. However, in the core catcher of Core 10, the absence of $D$. alata, rare occurrence of $D$. dentata, and the presence of Eucyrtidium diaphanes and Liriospyris stauropora indicate the uppermost lower Miocene Calo- 


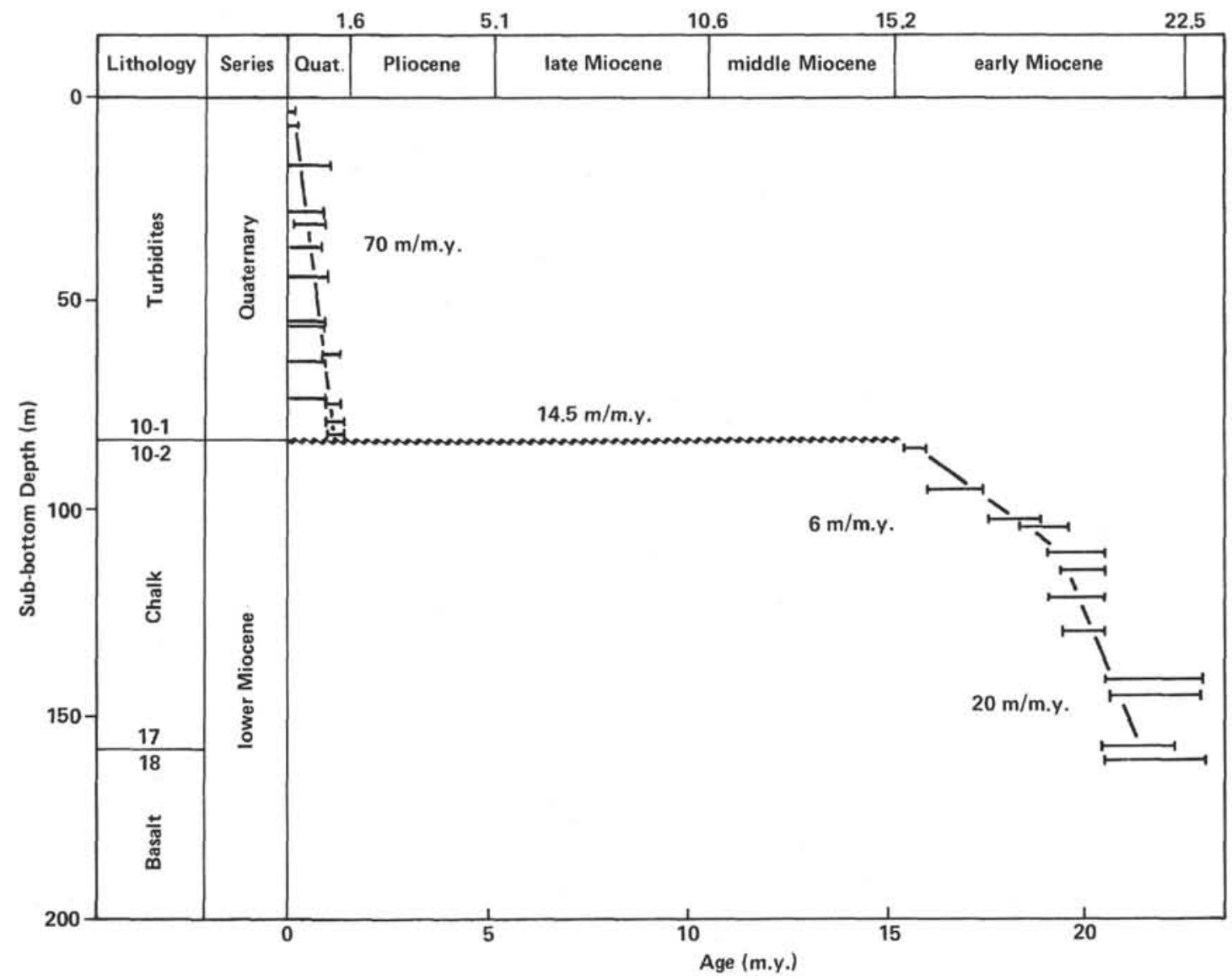

Figure 9. Sedimentation rate curve for Hole 500. (Numbers in the Lithology column refer to core and section.)

cycletta costata Zone. The drill breccia of Core 11 contains individuals of both these zones as well as Didymocyrtis penultima (upper Miocene-Pliocene) and $D$. tetrathalamus (Pliocene-Pleistocene).

At Sample $500-12-3,127-129 \mathrm{~cm}$, the absence of $C$. costata and D. dentata, abundance of Stichocorys wolffii, and rare occurrence of Lychnocanoma elongata indicate the $S$. wolffii Zone of approximately $19 \mathrm{~m} . \mathrm{y}$. of age.

Samples from both Cores 13 and 14 contain radiolarians from the lower Miocene $S$. delmontensis Zone. These assemblages appear better preserved than those of the corresponding cores at Sites 499 and 495, and diatoms are far more abundant in the strewn slides. However, just as at Sites 499 and 495 , the remaining cores above basalt are barren of radiolarians.

\section{Nannoplankton}

The upper Quaternary turbidites at Hole 500 (Cores 1 to 10 , Section $2,50 \mathrm{~cm}$ ) contain an assemblage of $\mathrm{Ge}$ phyrocapsa oceanica Zone with zonal species small $\mathrm{Ge}$ phyrocapsa and Emiliania, Cyclococcolithina leptopora, Helicosphaera kamptneri, and reworked Pliocene Discoaster brouweri and Miocene Sphenolithus aff. belemnos, $S$. moriformis, $S$. heteromorphus, $D$. deflandrei. The preservation of nannoplankton is moderate to good, and abundance is rare to common.
The boundary between the turbidites and lower Miocene chalks occurs in Hole 500, Core 10. Quaternary muds found below this level in drilling breccia of Core 11 (core catcher) and in the upper part of Core 15 are the results of contamination. Chalks contain abundant nannoplankton with good preservation.

The zonal sequence of chalks in Hole 500 is as follows: (1) ?Sphenolithus heteromorphus/Helicopontosphaera ampliaperta Zones, Samples 500-10-3, 49-51 cm to $500-13-2,34-36 \mathrm{~cm}$, with $S$. heteromorphus, $D$. exilis, D. deflandrei. (2) D. druggii Subzone of Triquetrorhabdulus carinatus, Samples 500-14-1, 20-22 cm to 500-15-1, 46-48 cm, with Orthorhabdulus serratus $(12, C C), T$. carinatus, and $D$. aff. druggii. (3) D. deflandrei Subzone of the same zone, Sample 500-15-2, $45-47 \mathrm{~cm}$ to $500-17-5,56-58 \mathrm{~cm}$, with abundant $T$. carinatus and without $D$. aff. druggii.

\section{GEOCHEMISTRY}

\section{Organic Geochemistry}

The hydrocarbon monitoring program used at previous Leg 67 sites was continued at Site 500. Methane/ ethane ratios are shown on Figure 10. Ratio values were in excess of 100,000 throughout the entire section penetrated. Figure 11 shows the distribution of both meth- 


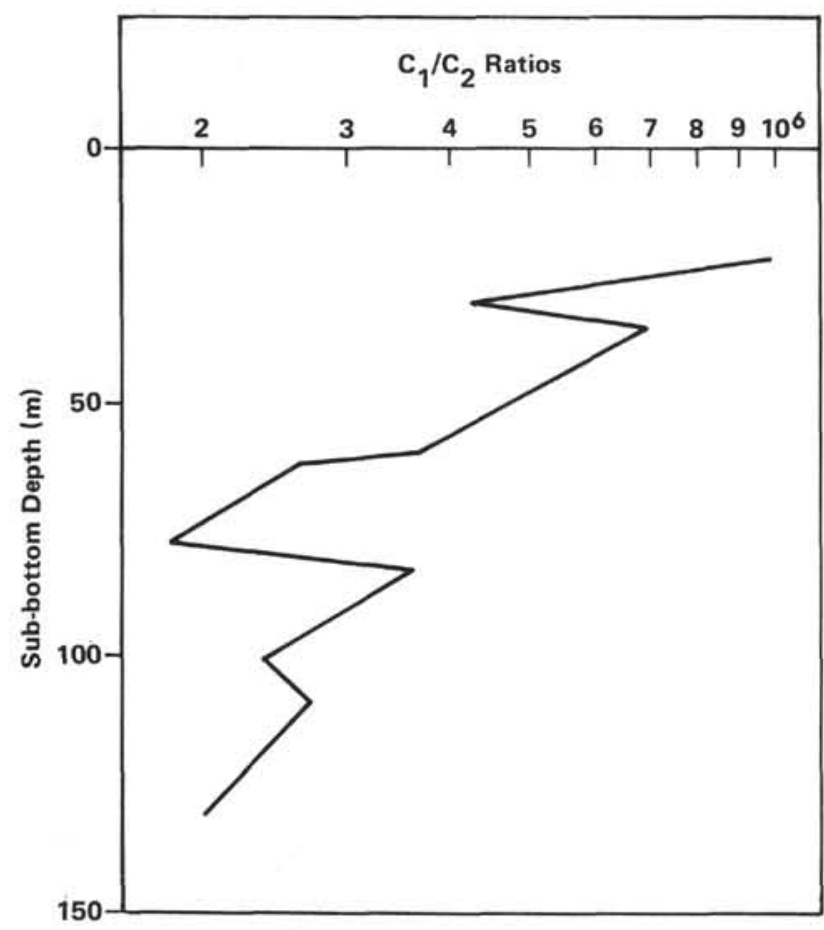

Figure 10. Methane-ethane ratios for Site 500.

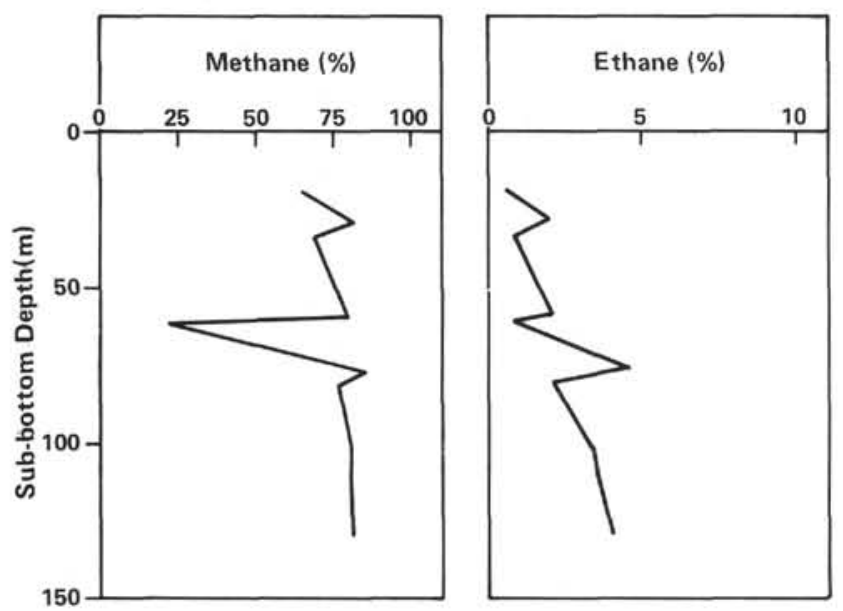

Figure 11. Methane and ethane concentrations at Site 500.

ane and ethane. Methane concentrations were on the order of $65 \%$ to $85 \%$ of total gas sampled and were similar to other Leg 67 sites. Concentrations of ethane were less than $5 \mathrm{ppm}$ and were among the lowest for Leg 67 sites.

\section{Inorganic Geochemistry}

Figure 12 illustrates the results of the shipboard interstitial water program. As at several other Leg 67 sites, salinity, magnesium, and calcium have similar profiles when plotted against depth. The $p \mathrm{H}$, chlorinity, and alkalinity values remain fairly constant throughout the penetrated section.

\section{SUMMARY AND CONCLUSIONS}

\section{Summary of Data}

Site 500 is at the base of the Middle America Trench landward slope at or near the juncture of the slope and the trench floor. We formulated the objectives at this site aboard the Challenger, assuming that sampling could be done with the Hydraulic Piston Corer (HPC); however, it failed to operate properly. We had just used the last positioning beacon on board, therefore some of the original objectives were given up. But by reverting to normal coring and releasable bit, a last chance to log was provided. Three holes were positioned using the beacon at Site 500, and one hole (499D), for logging, was washed down using the 499 beacon for positioning.

The lithologies and ages encountered are basically the same as at Sites 499 and 495 , but there are some differences. In Hole 500 the Quaternary trench-fill turbidite sequence is either faulted or deposited against a fault scarp in lower Miocene chalk; basalt basement is at a sub-bottom depth of 161 meters. Coarse basalt and sandstone rubble were encountered at sub-bottom depths of 114 and 125 meters, respectively, and proved undrillable. Neither the basement nor the rubble zones can be clearly identified in seismic records, although in hindsight, a strong reflection in GUA-13 may correspond to the basement at Hole 500 .

Structurally, the bedding in both the turbidite and chalk units is nearly horizontal, as is suggested by seismic records. Turbidites are thicker at the center of the trench axis, Holes 500A and 500B, than near its border, Hole 500. The chalks preserve structures like one or two local, small (less than 50-mm displacement) reverse faults and well-developed slickensided normal fault. Some of the small reverse faults may be caused by synsedimentary deformation, and they are no better developed at this site than at Site 495 .

Generally, the section at Site 500 shows no more deformation than the equivalent sections at Sites 499 and 495. A large normal fault between turbidite and chalk cuts out at least 100 meters of section. In the brittle chalk, which should be readily deformed, compressional deformation is not evident.

Biostratigraphy, as lithostratigraphy, is a repeat of the oceanward sites. Surprisingly, the depositional rate of trench-fill turbidite is about one-third the rate previously observed. This reduced thickness could result from our not having recovered the base of the turbidite. The trench fill has biogenic components such as wood fragments more characteristic of slope deposits at Site 494 than the turbidites at Site 499.

Physical properties of the section at Site 500 are not much different from those at Site 499 . The first 80 meters appear underconsolidated, and the last 40 meters are slightly overconsolidated. This pattern is common at the Leg 67 sites.

The composition of gaseous hydrocarbons is predictable. Ethane values are low and most of the gas is methane. Anoxic conditions may exist in the trench, as 


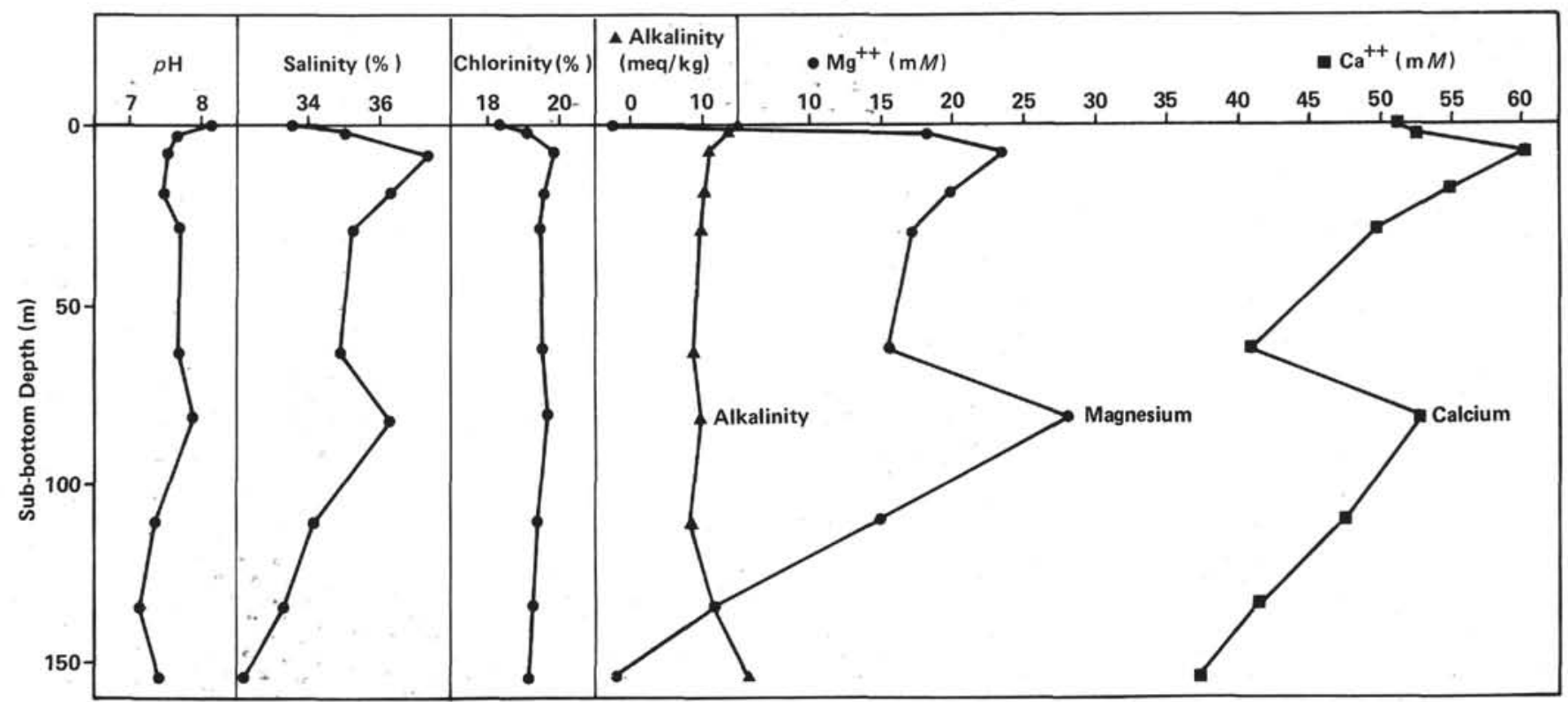

Figure 12. Interstitial water studies at Site 500 .

indicated by the development of the large amount of pyrite and $\mathrm{H}_{2} \mathrm{~S}$, even in some cores of the chalk.

\section{Conclusions}

Site 500 , at the front of the subduction zone, shows deformational features and physical properties that are essentially the same as at Sites 499 and 495 . The largest structure appears to be a normal fault, but it is uncertain whether it represents downfaulting from the oceanward or landward side (a landward or seaward dip); however, it is interpreted as a structure inherited from normal faulting along the trench seaward wall. This conclusion is based not only on the drill data but on the results of a postdrilling Seabeam bathymetric survey (Aubouin et al., this volume).

The complexity of the trench at Sites 499 and 500 was unexpected from seismic records alone. Moreover, one or two holes would not have documented the variability of depth to basement, the rubble horizons, and the lack of compressional structure discovered by drilling a network of eight holes. The limited resolution of the seismic-reflection technique is demonstrated by comparing the two multichannel, three single-channel, and two $3.5-\mathrm{kHz}$ seismic-reflection records at these sites with the drilling results.

\section{REFERENCES}

Coulbourn, W. T., 1981. Tectonics of the Nazca Plate and the continental margin of western South America. In Hussong, D., Kulm, L., and Wollard, G. (Eds.), The Nazca Plate Project. Geol. Soc. Am. Mem.: Boulder, Colorado, pp. 587-618.

Isacks, B., and Molnar, P., 1971. Distribution of stresses with descending lithosphere from a global survey of focal mechanism solutions of mantle earthquakes. Rev. Geophys. Space Phys., 9: 103-174. 

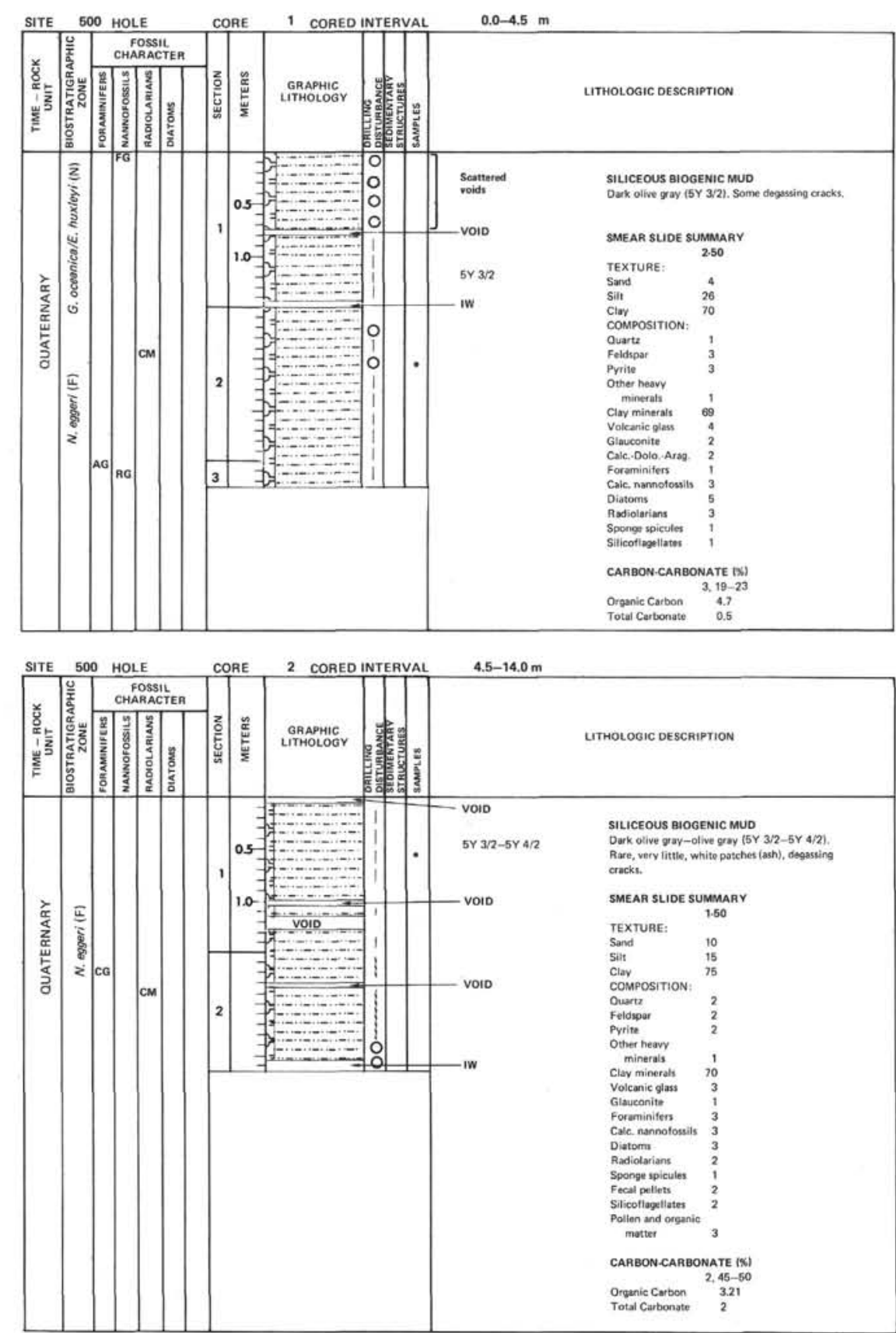

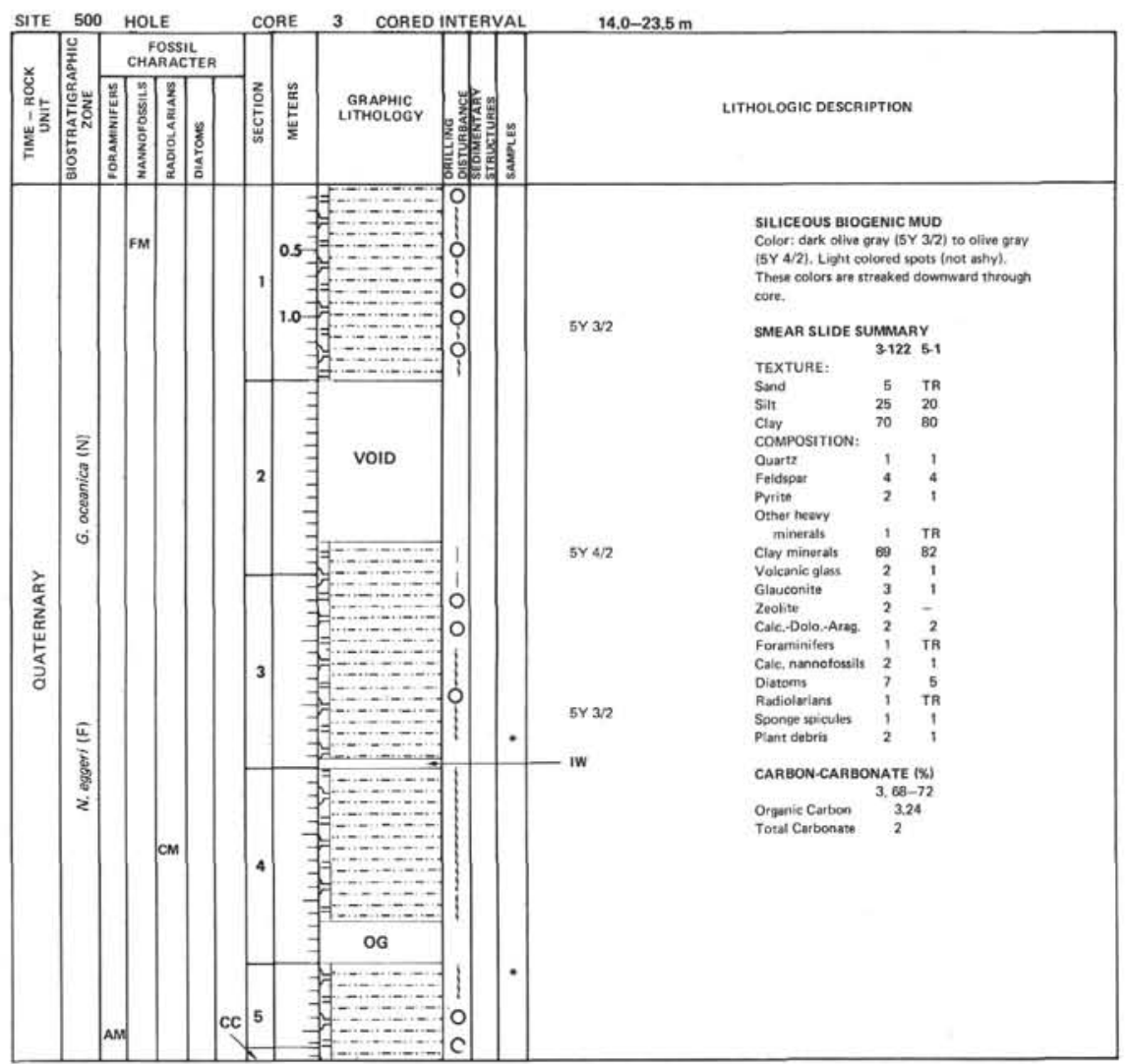



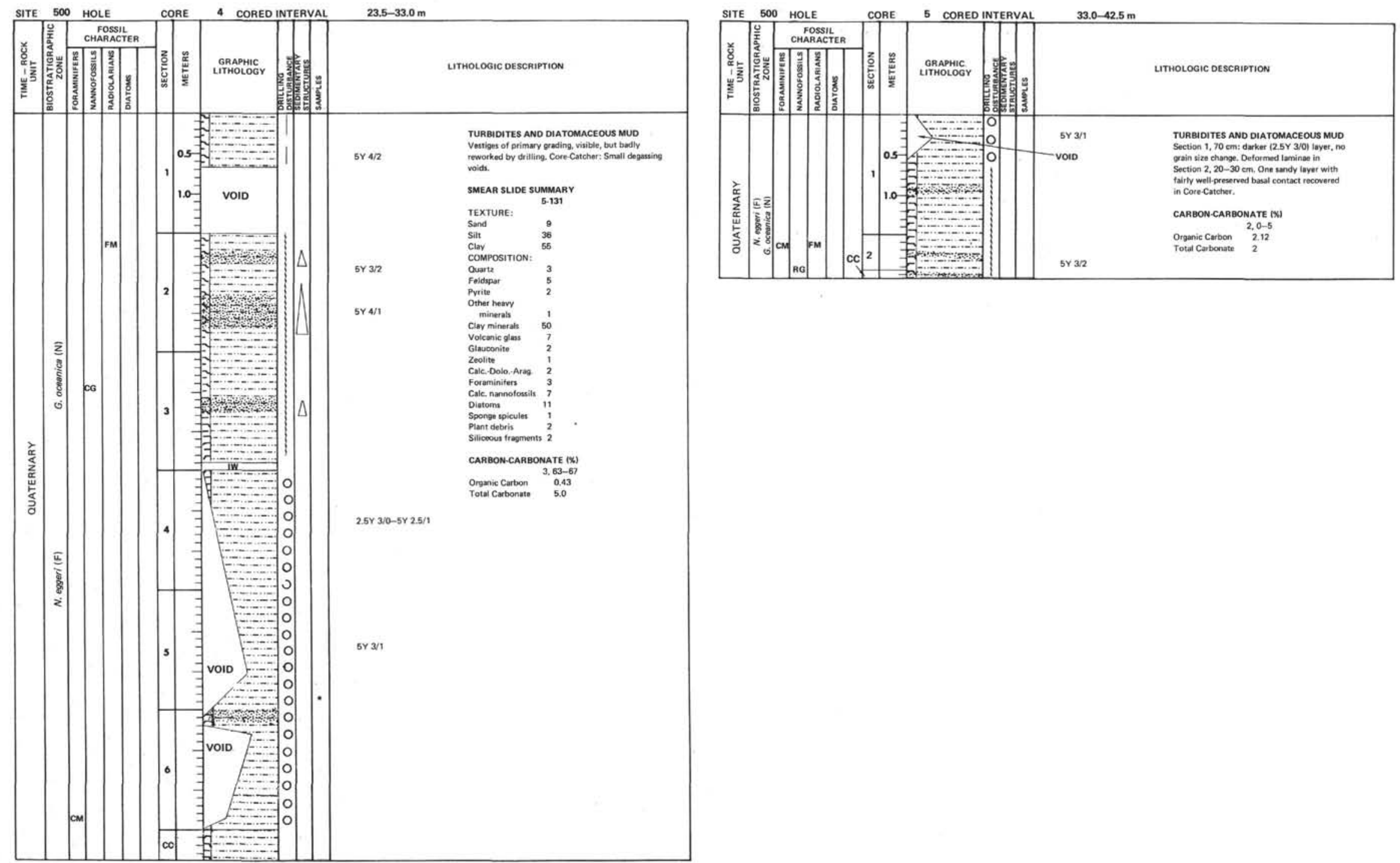

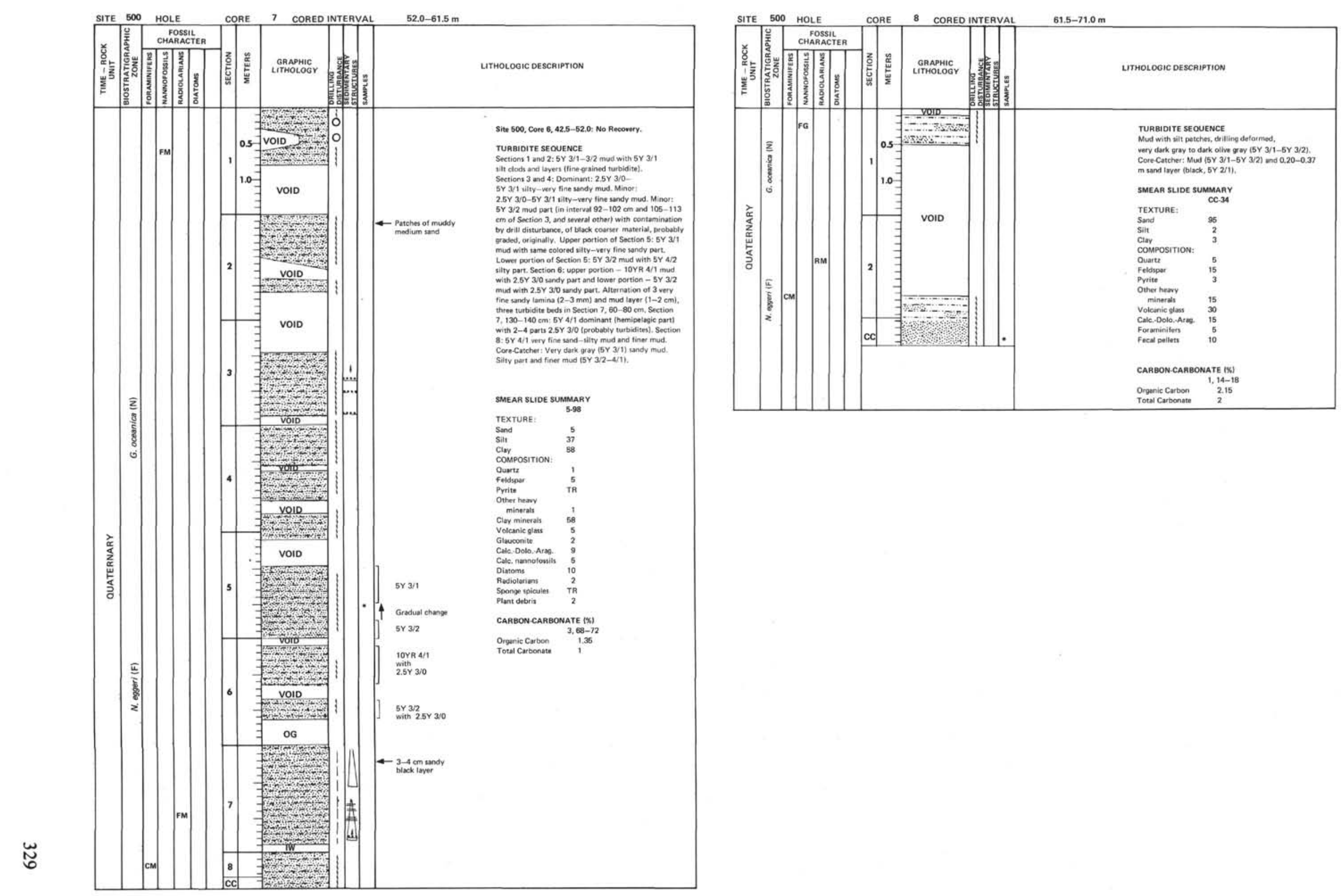

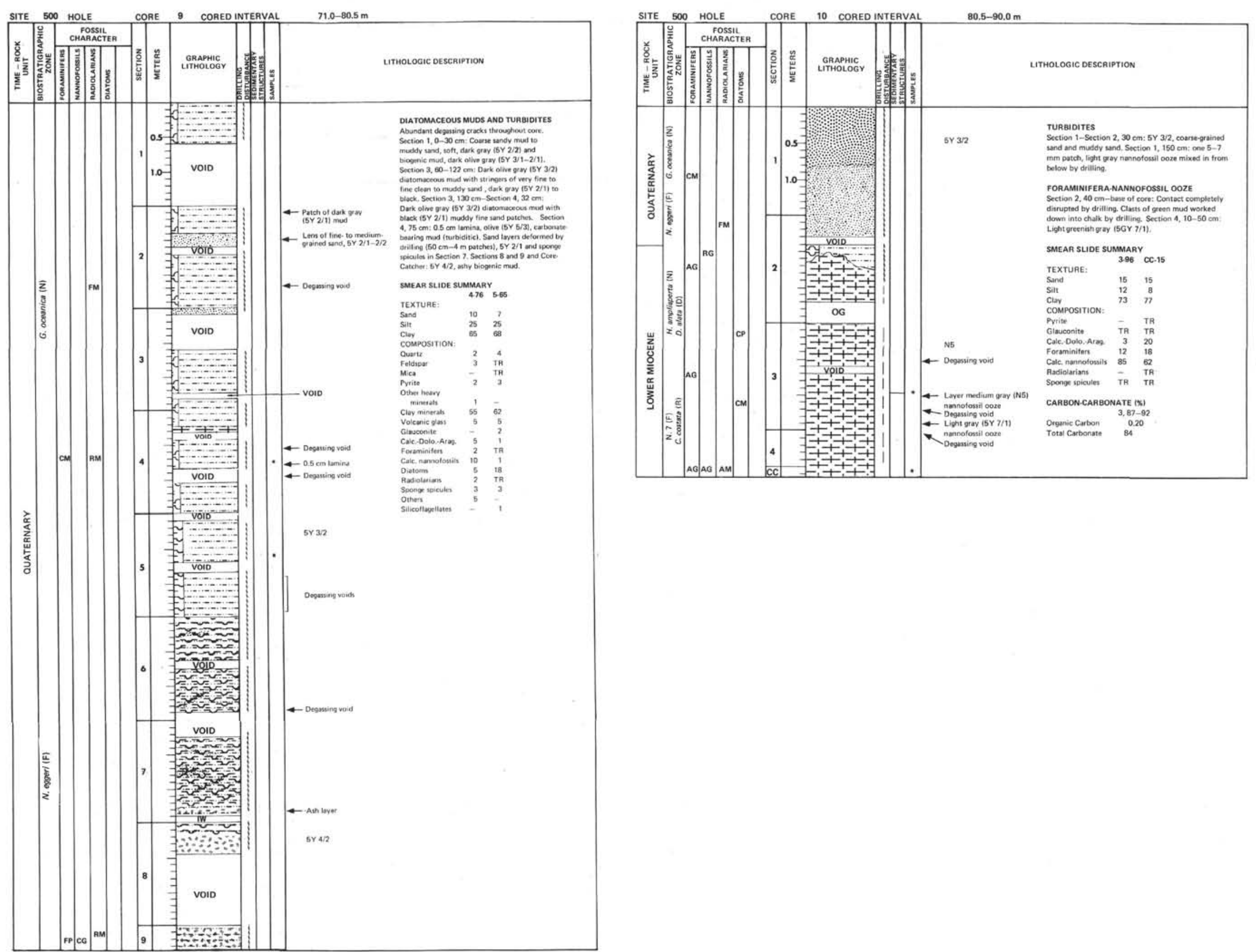

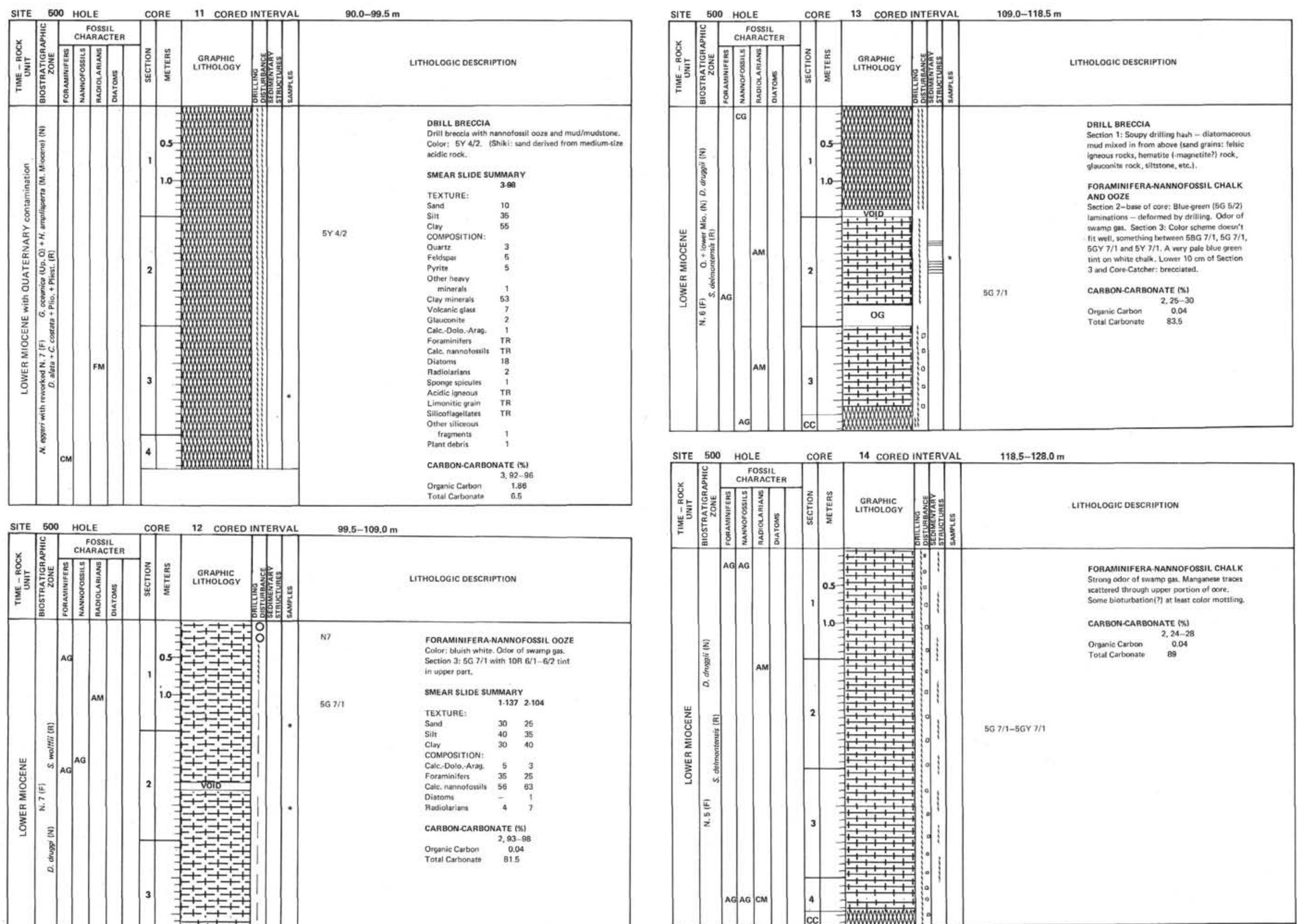

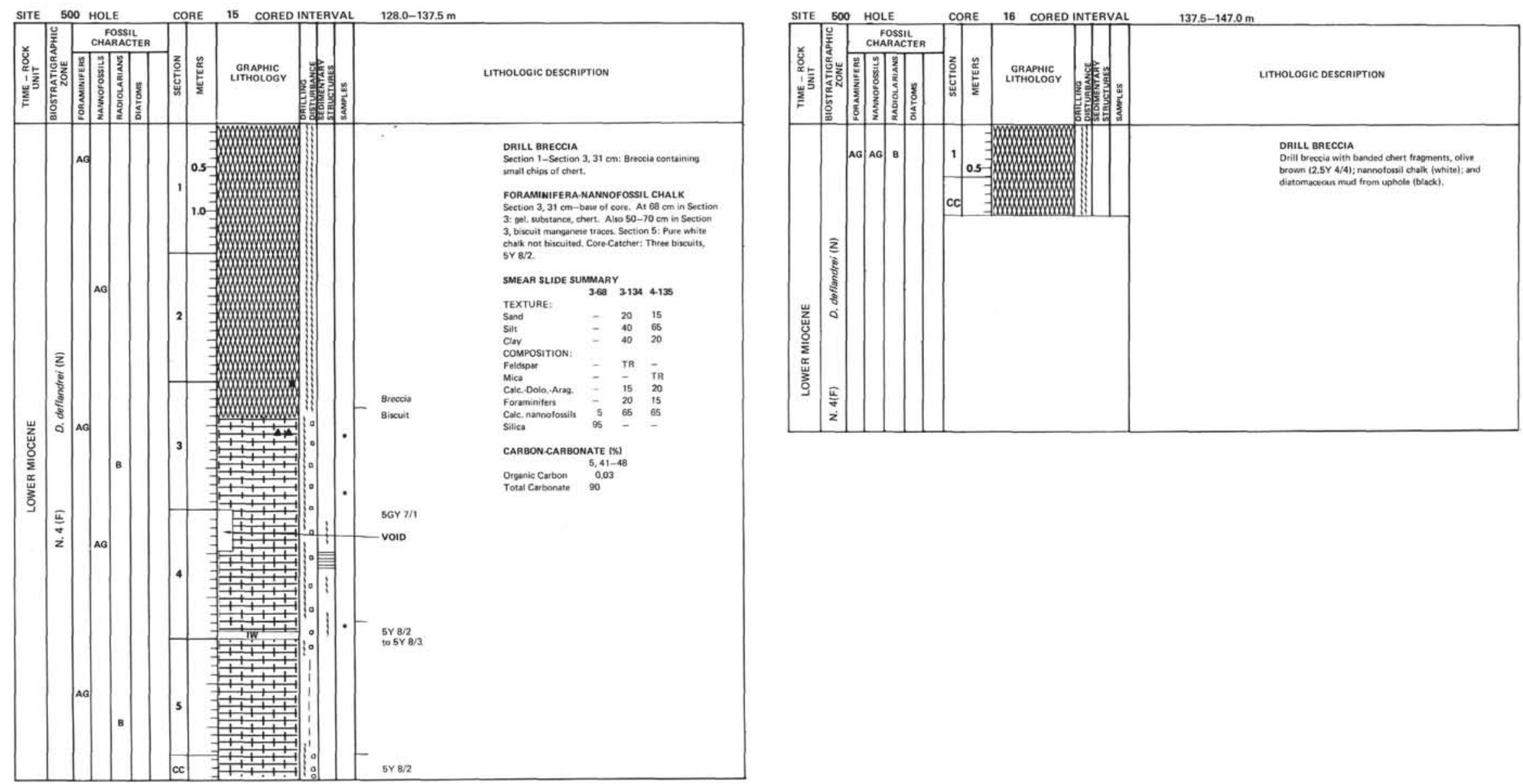


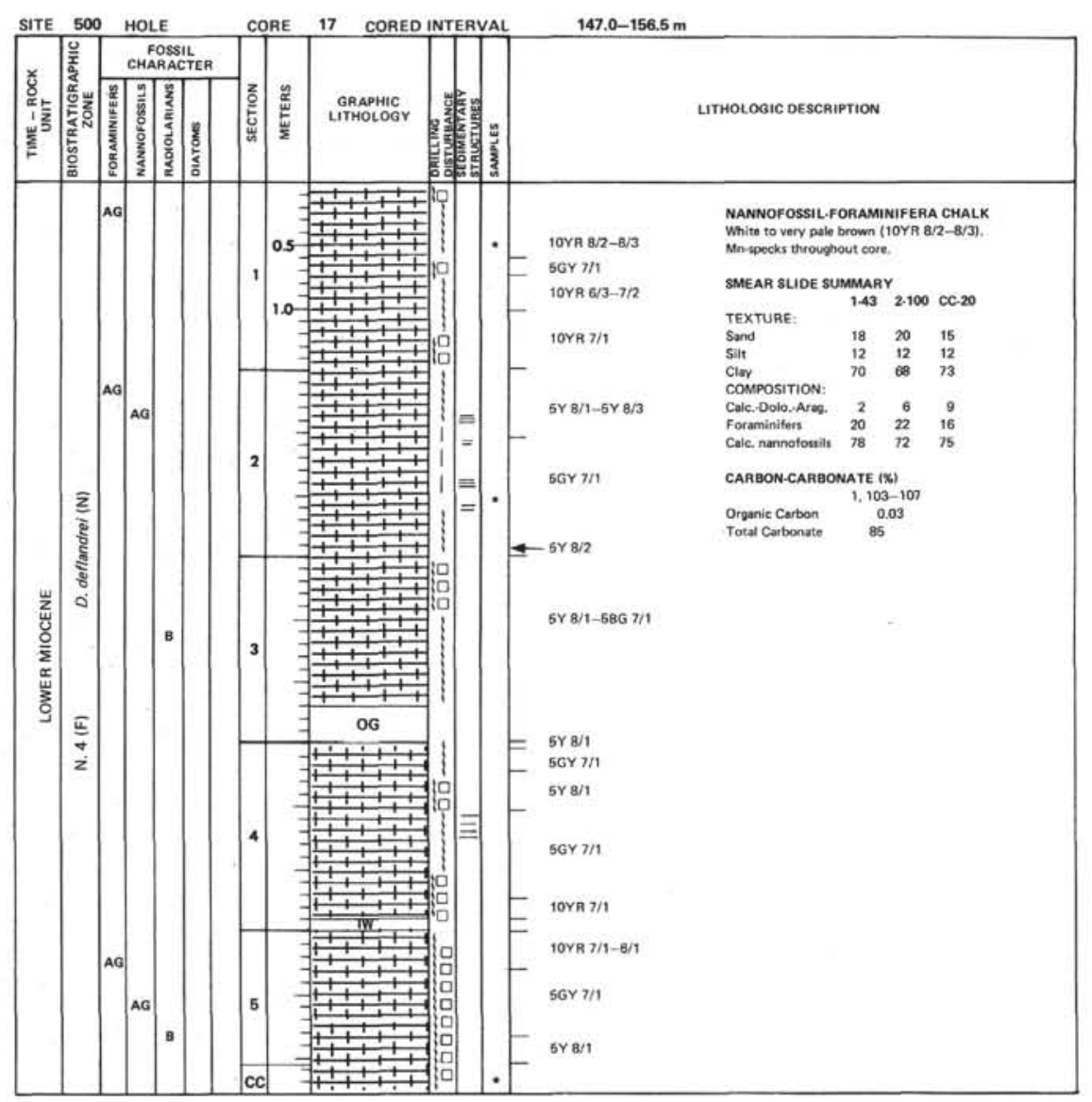




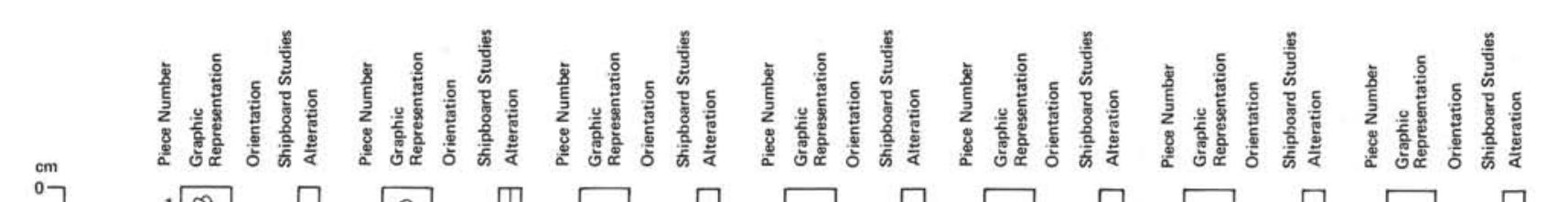

Macrosoopic Desceription
Dark gray to black fresh very fine-grained microphyric to aphyric in diameter, in some cases probably altered to clay minerals grevenish) 18 or less plasgoclasse microphenoccrysts $2-3 \mathrm{~mm}$ long. Groundmass aphyric, Pieces 1,2 , and 4 hines layers. Piece 5 has $\mathrm{o} 2 \mathrm{~cm}$ glassy rim $15 \mathrm{~mm}$ thick): Pieces 1,2 , and 7 .

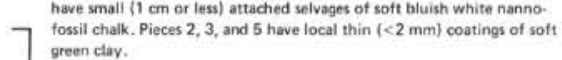

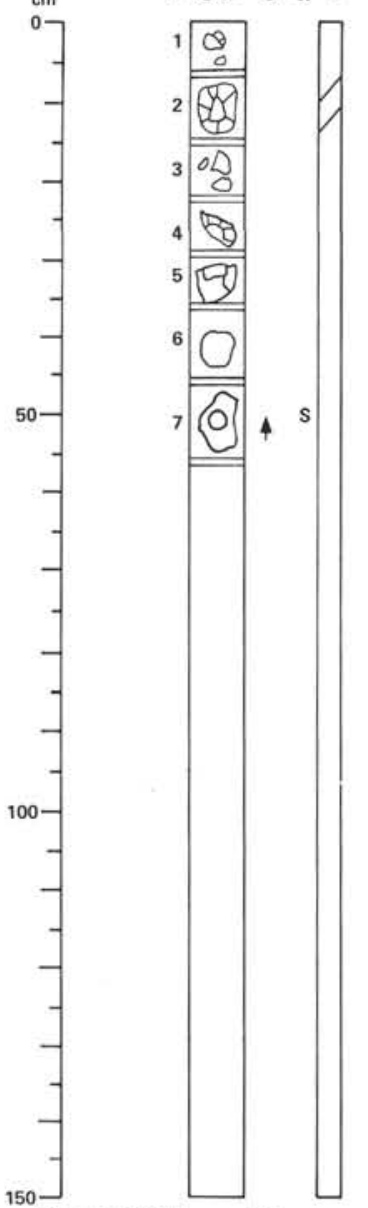

CORE/SECTION
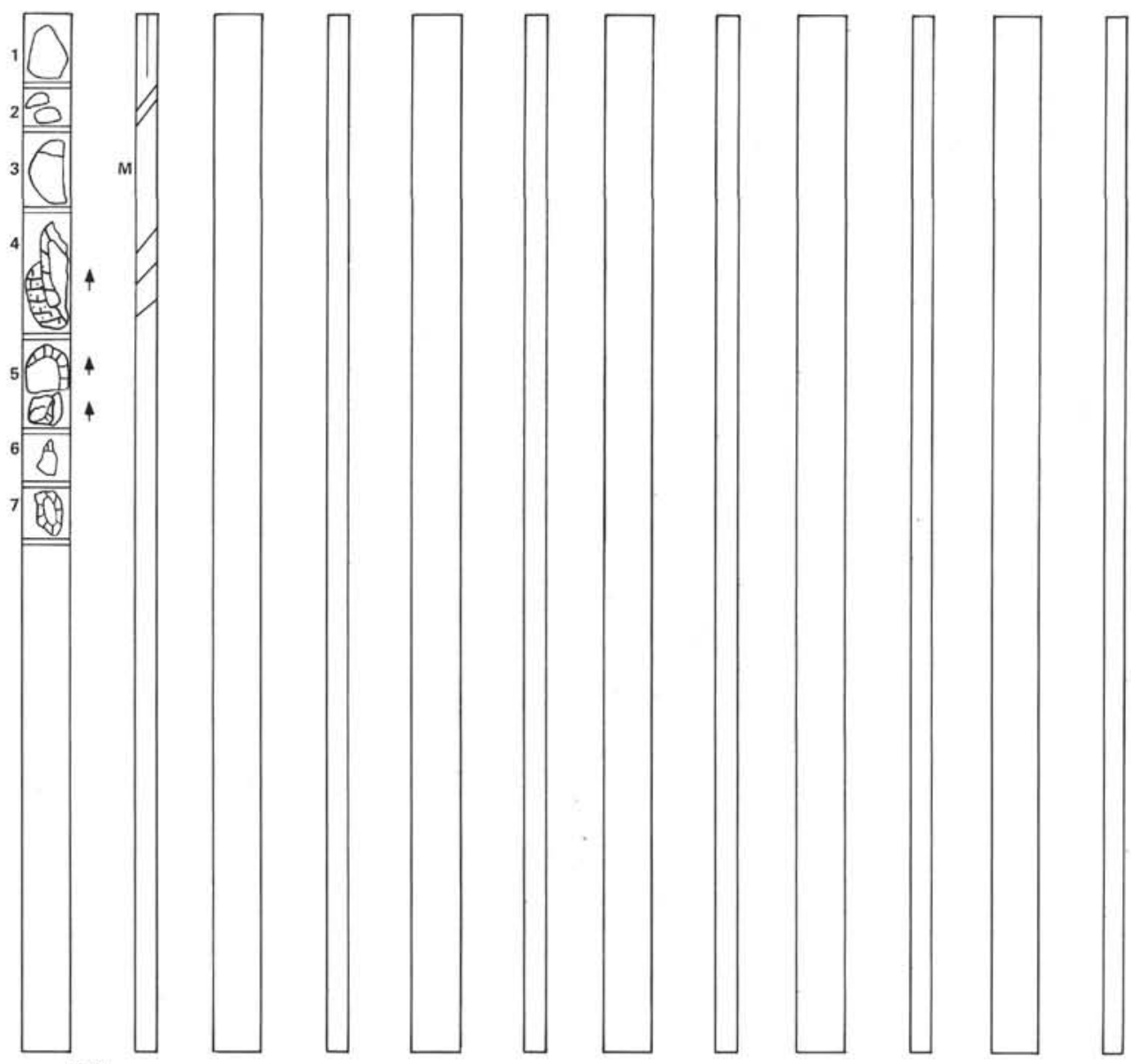

67.500-19

SECTION

Macroscopic Description

, $3,4,5$, and 6 . Fresh dark gray to black phyric basalt with tan ocerysts $2 \mathrm{~mm}$ long; 28 or less microphenocrysts of olivine (?) attered to

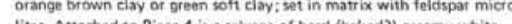

lites. Attached to Prieces 4 is a selvage of hard (boked)? creamy white

tains subrounded to angular fragments of tan bawit, and derik green

sott clay containing piagioclase microlites (probably was plassy). Tan westhered zone $1 \mathrm{~cm}$ thid adjacent to chalk. Piaces 4 allso contains 5

clase phenocrysts up to $4 \mathrm{~mm}$ long: 22 brown phyric basalt; 78 plagio. $\begin{array}{ll} & \\ & \end{array}$ of pieces locally coated with druses of soft green to vellow green clay. - Cavities and vesicles partly lined with druses of calcite end pole green clav.

-

$-$

- 

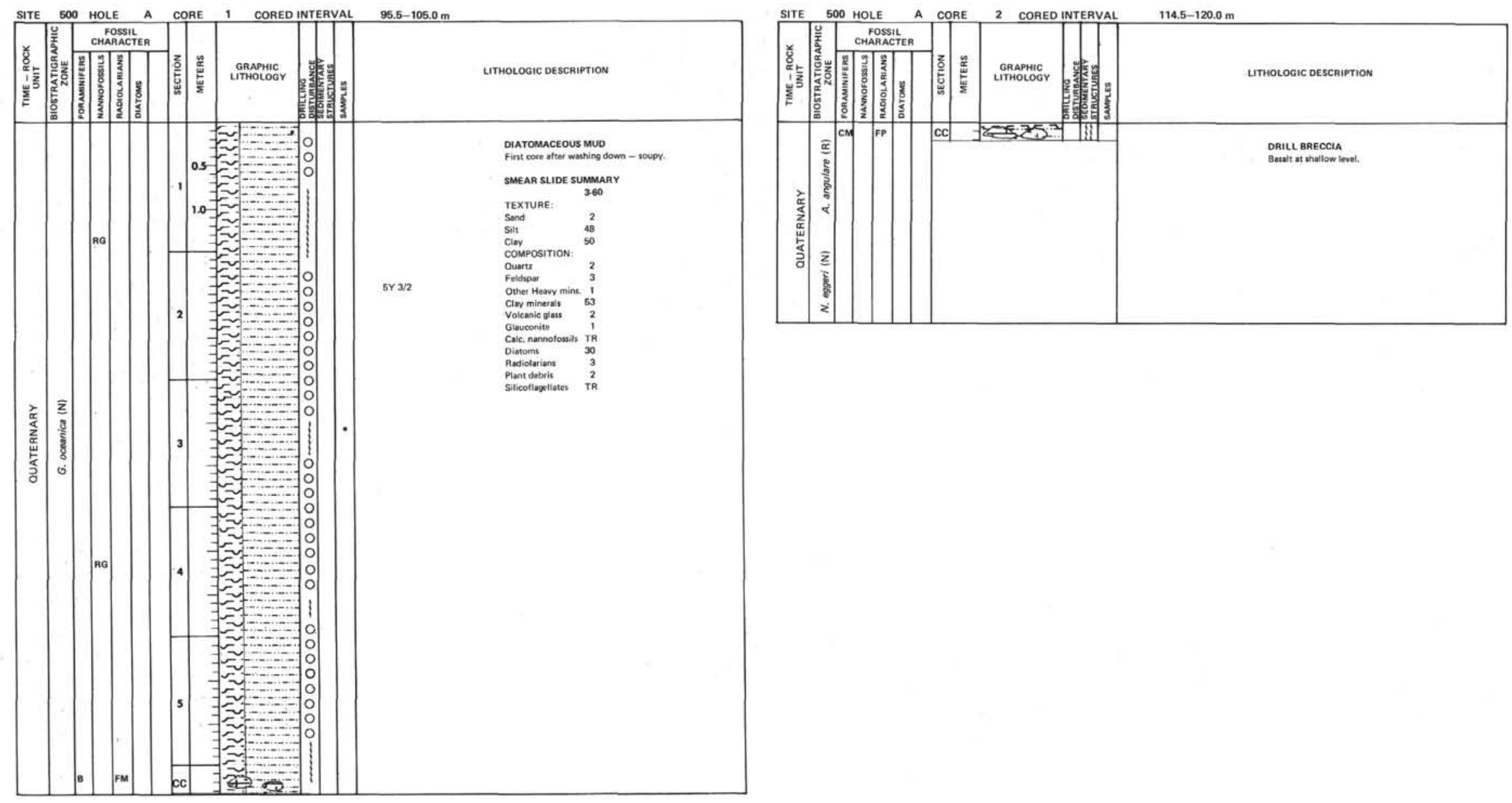

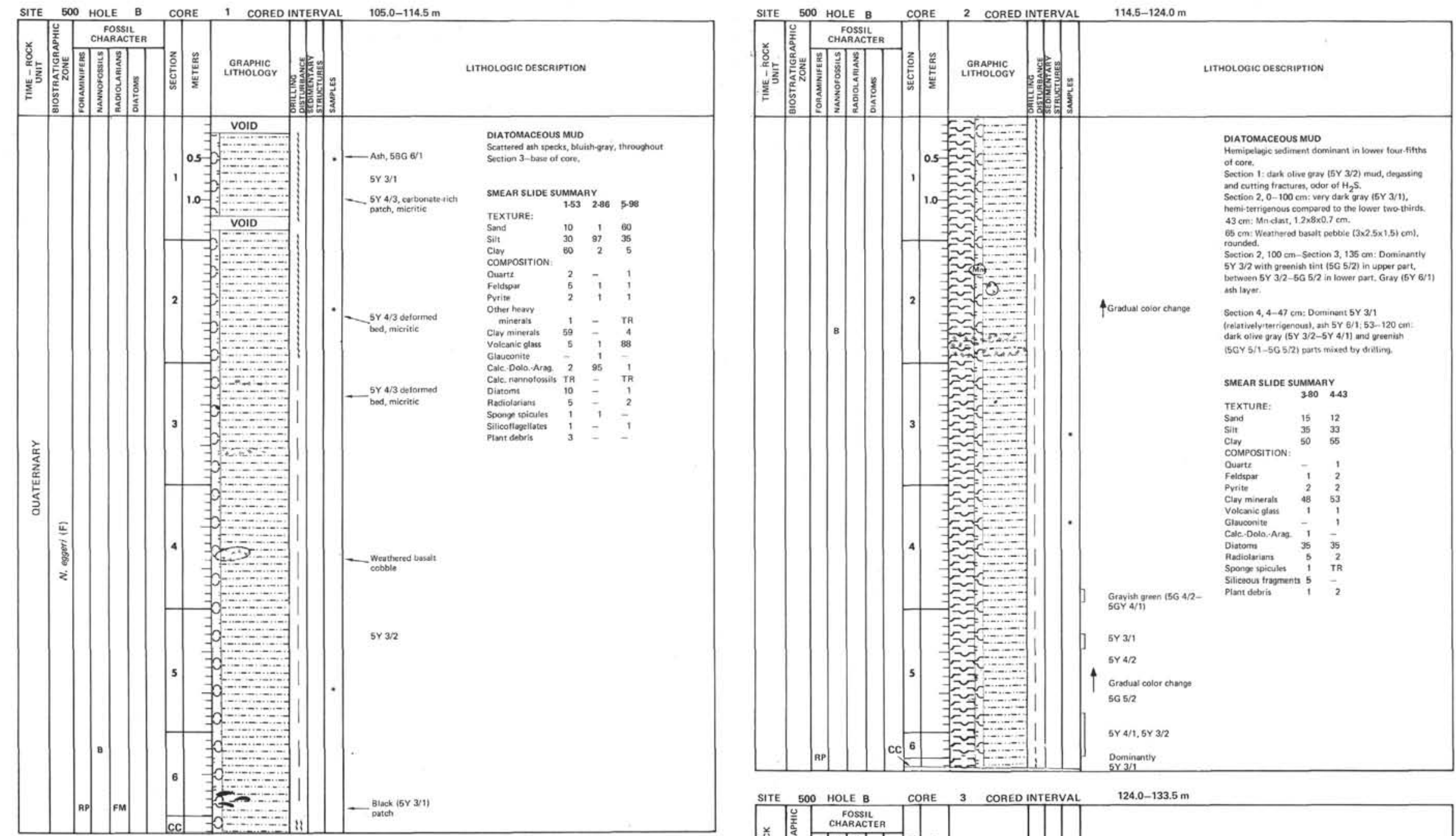

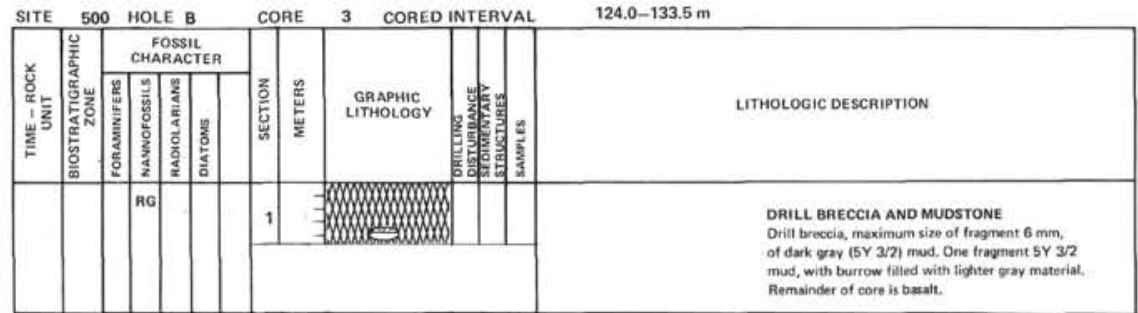




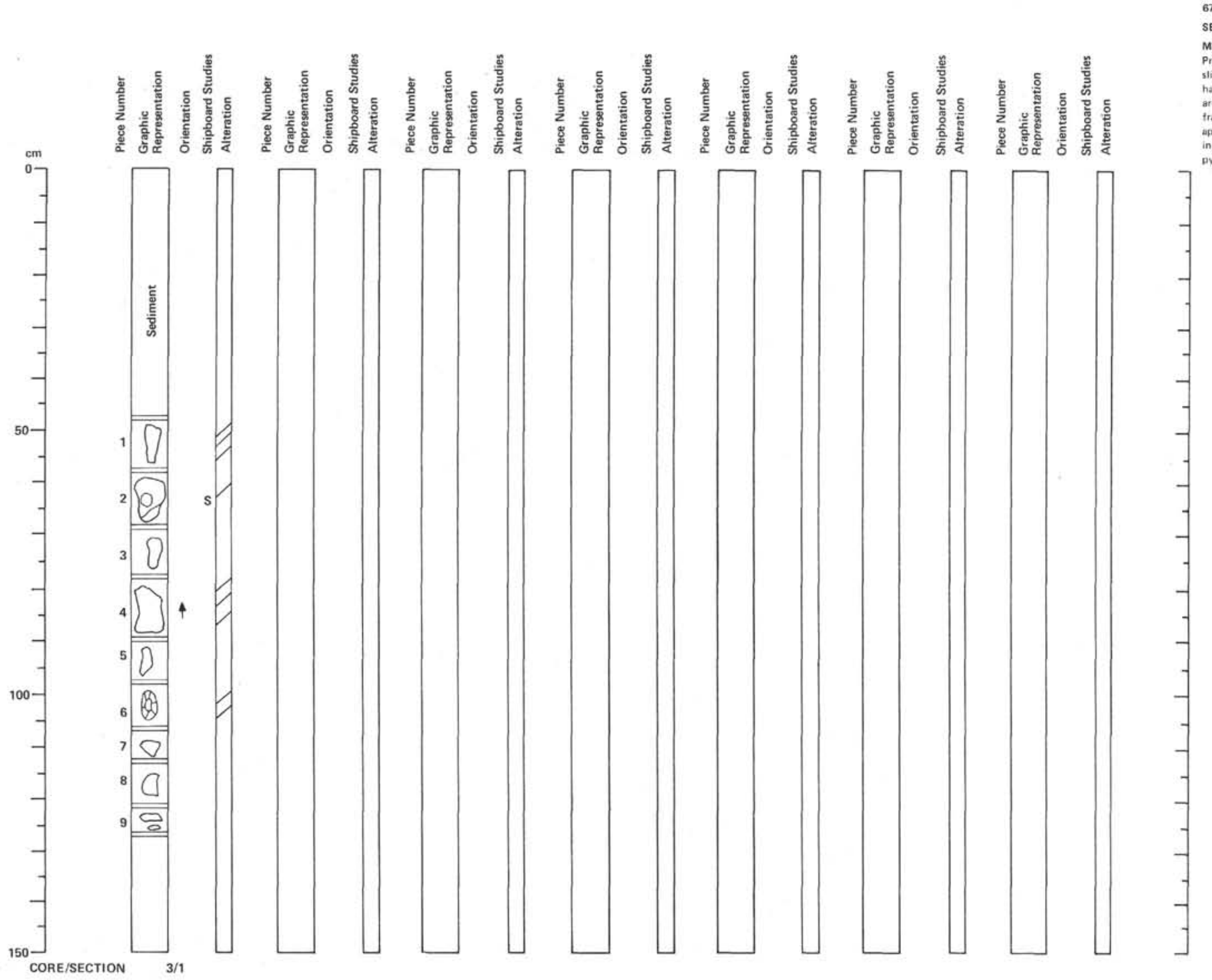

67.5008-3 Depth 124.0-133.5 m ECTION 1

Predominantly fine-grained aphyric dark to medium gray, fresh to Whitiv altered basalt. Plagioclase miccolites in groundmass vis bla with incally very abundant, probsobly along veins. Druses of calcite on in dark green gray groundmass; very fine-grained widely disseminated
pyrite 28 .

- 


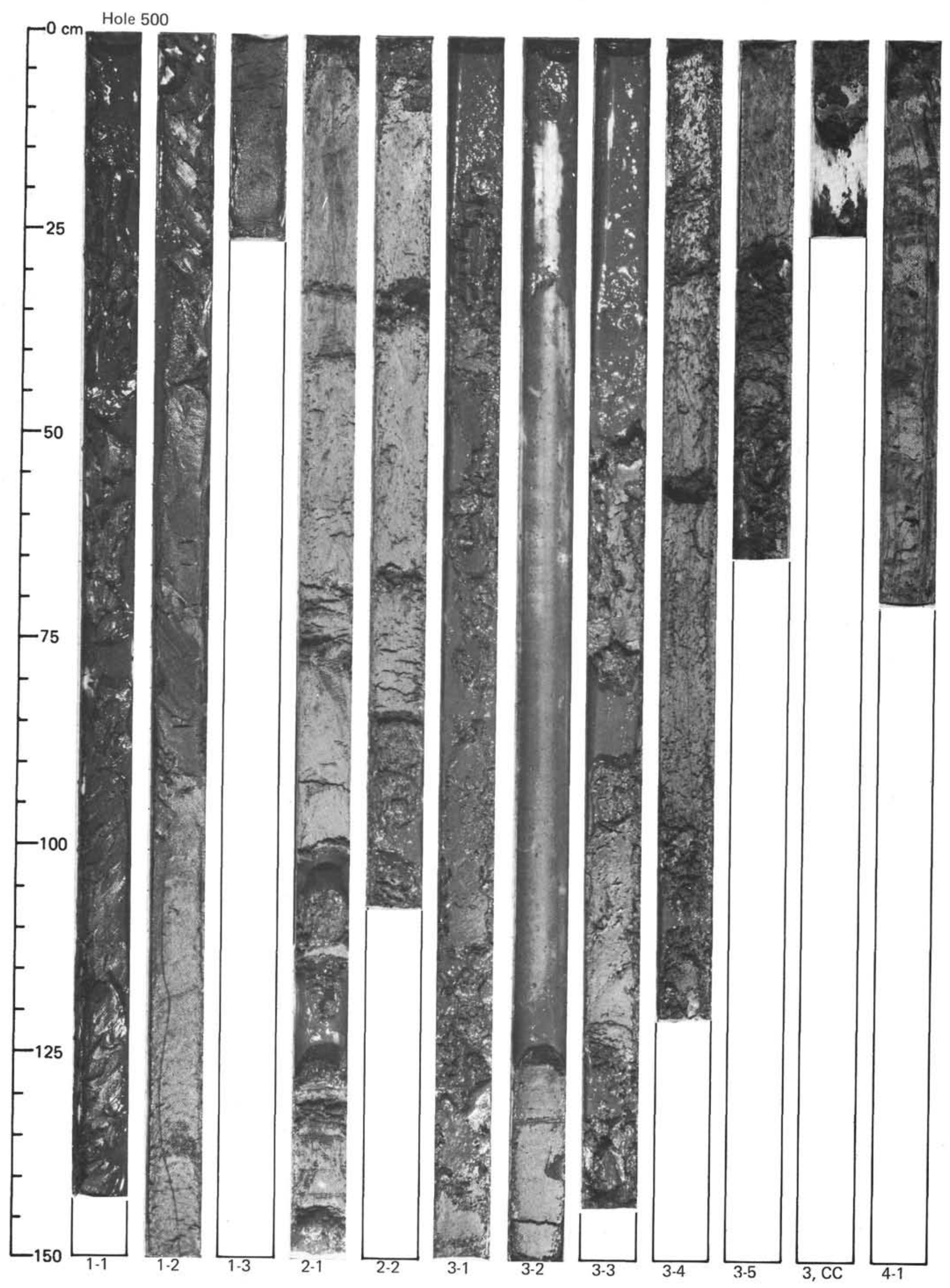



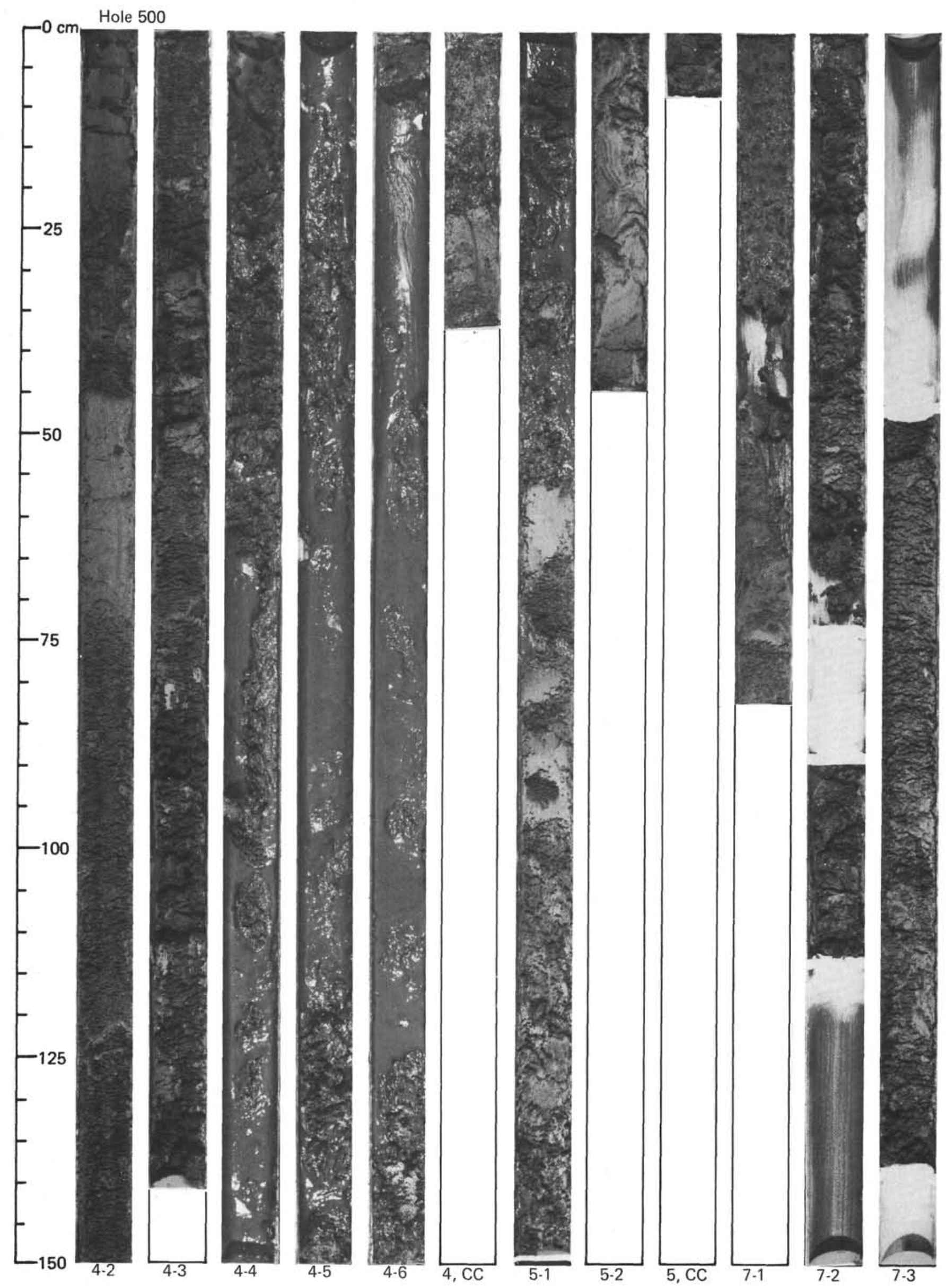


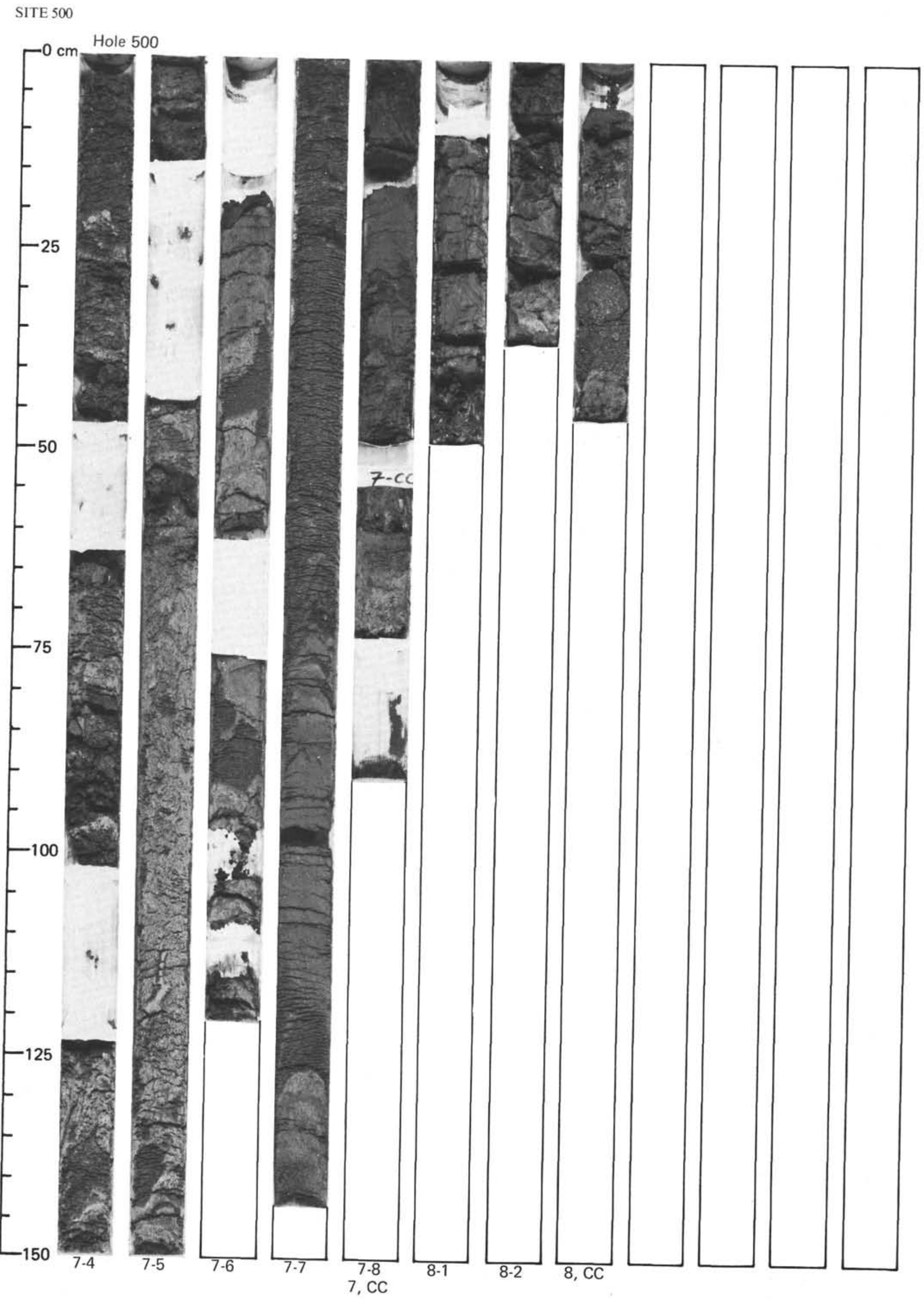



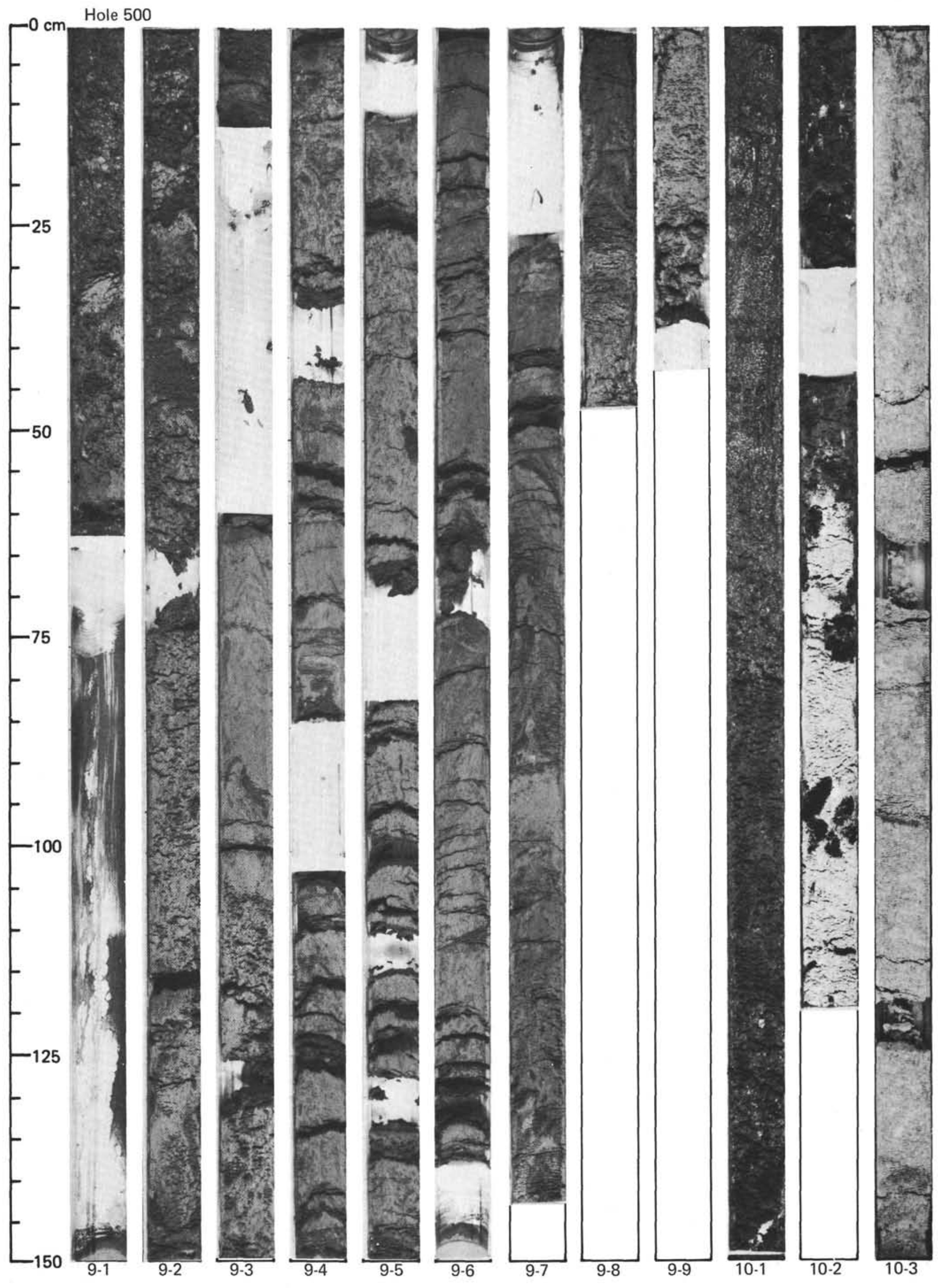


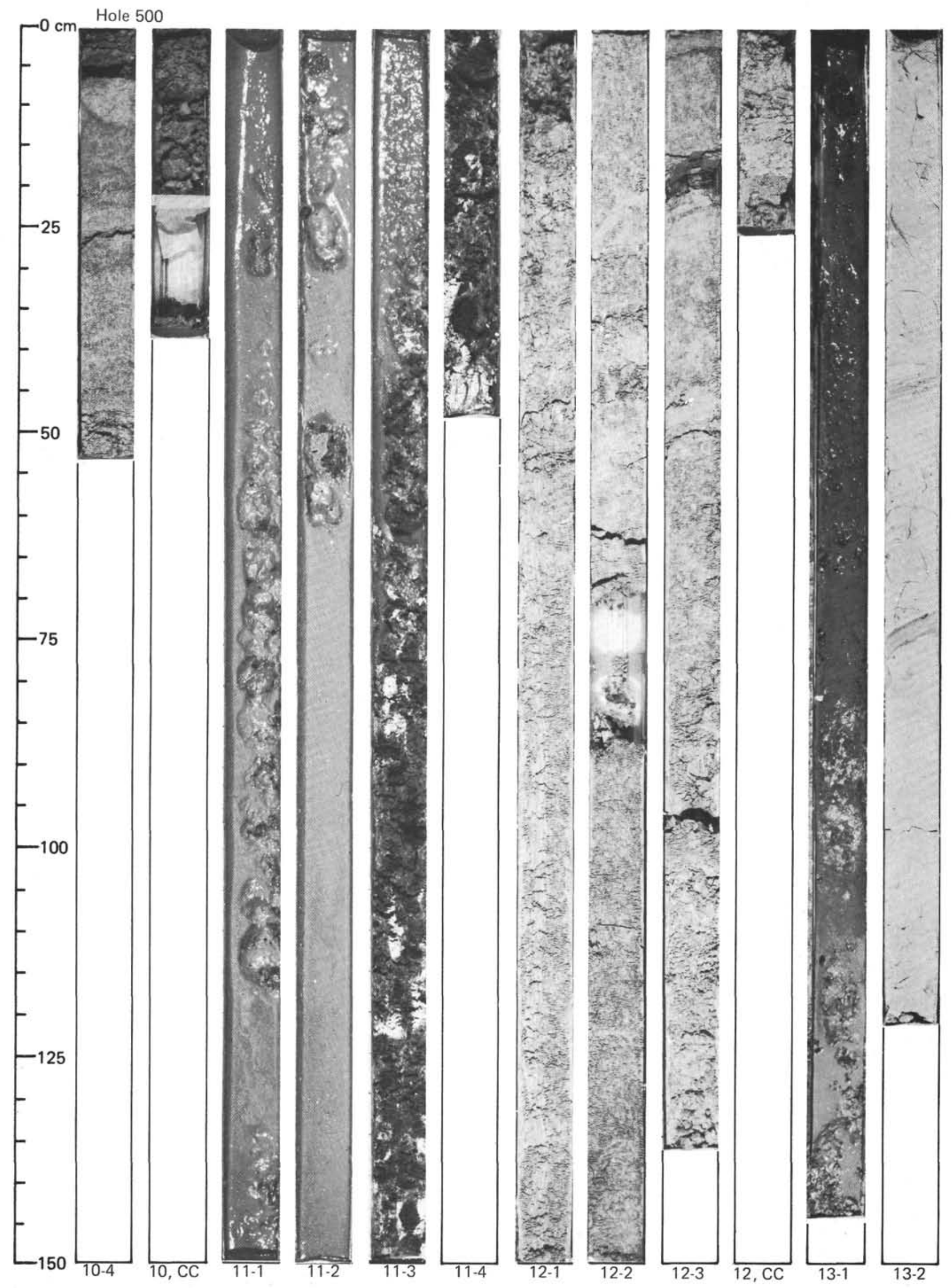



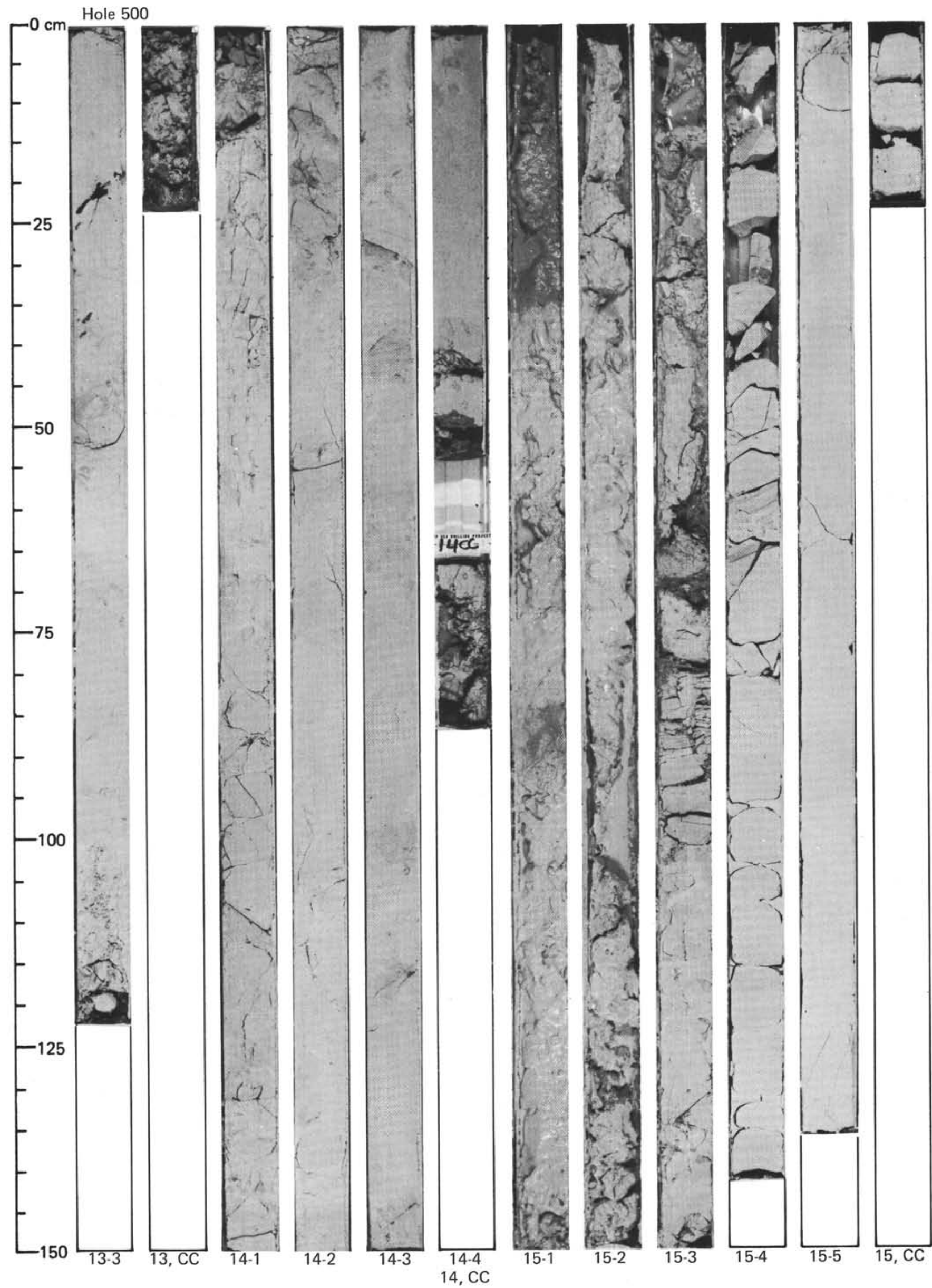

15-2 15-3

$15-4$

15-5 


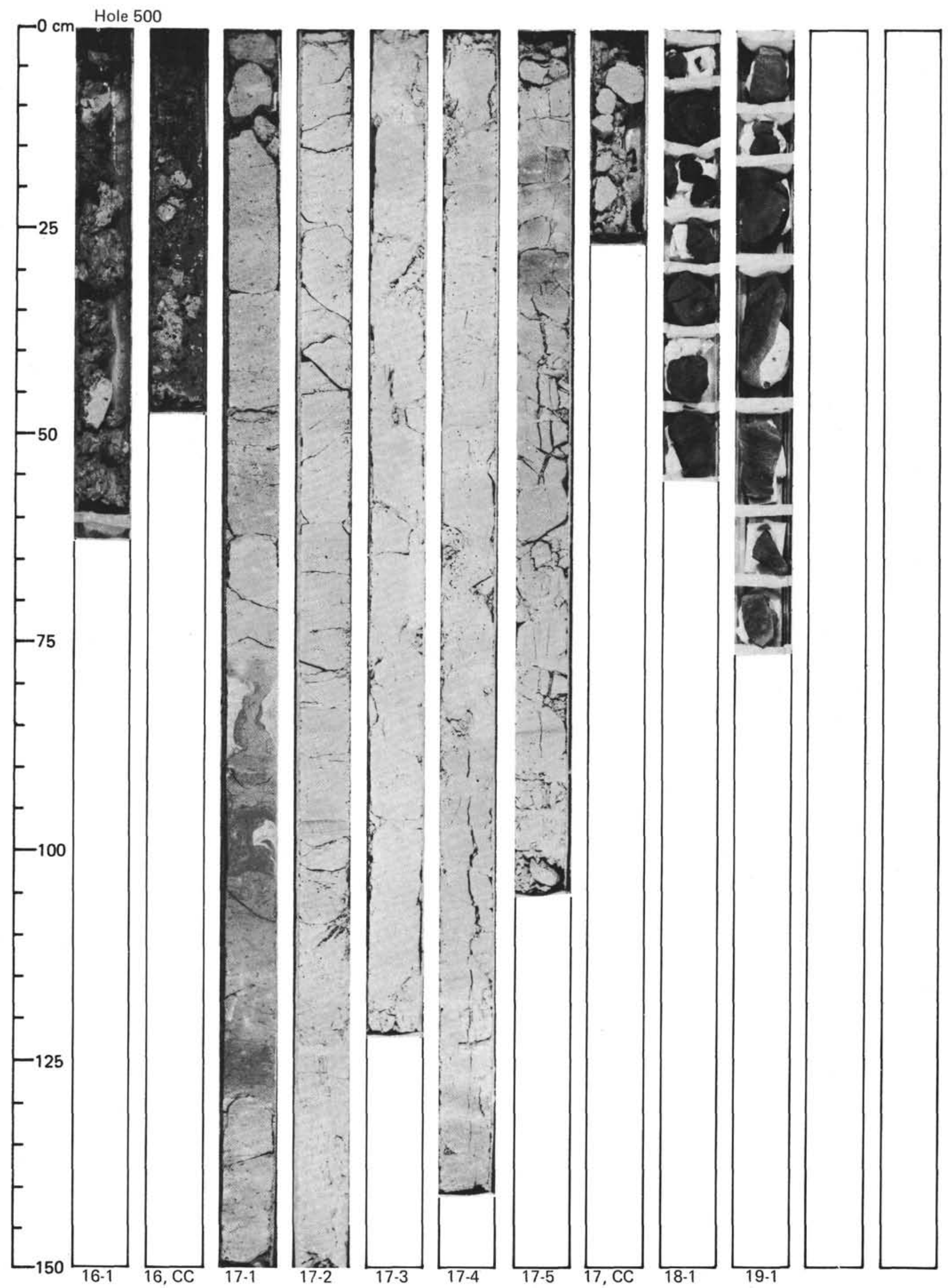




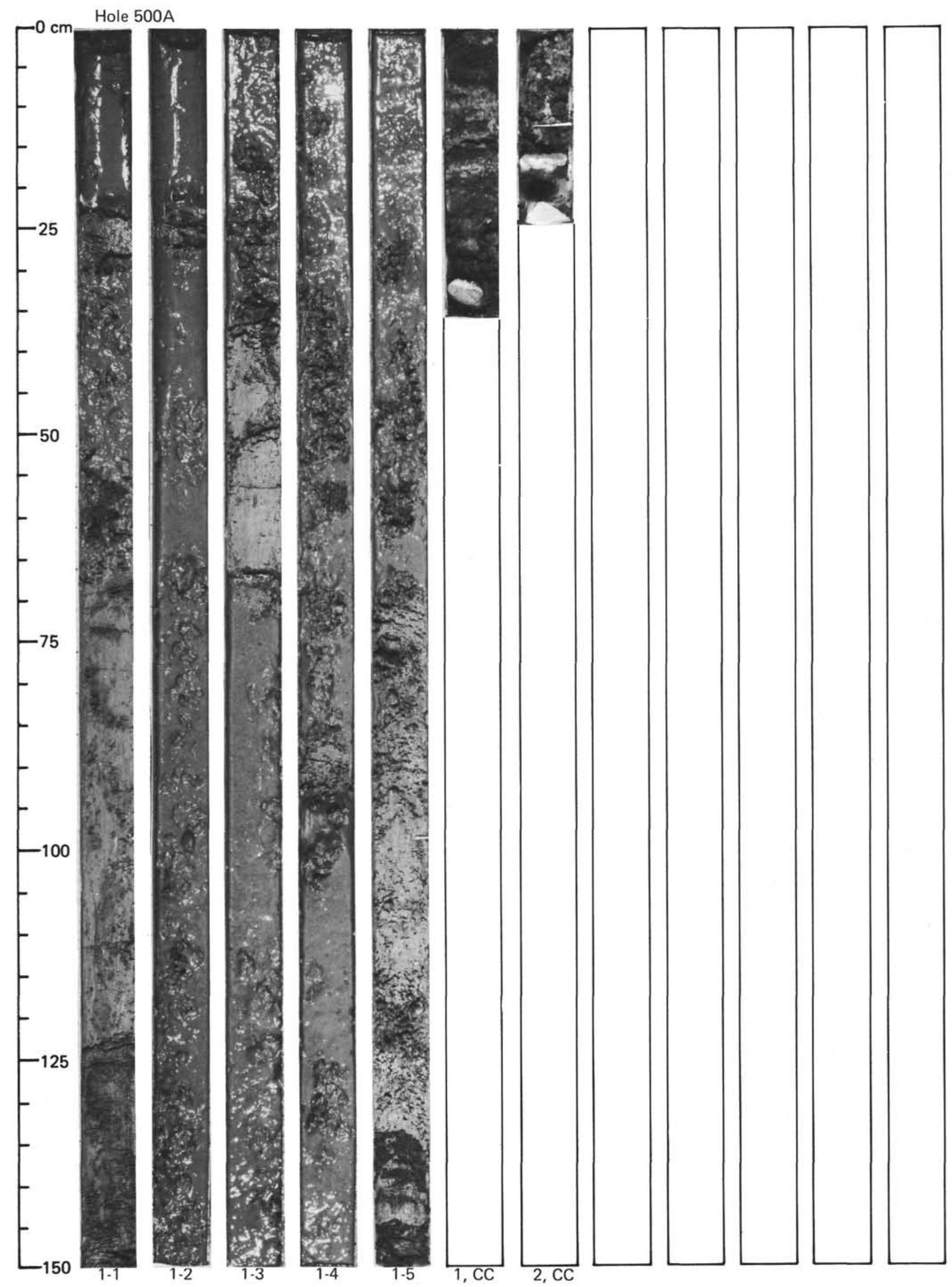




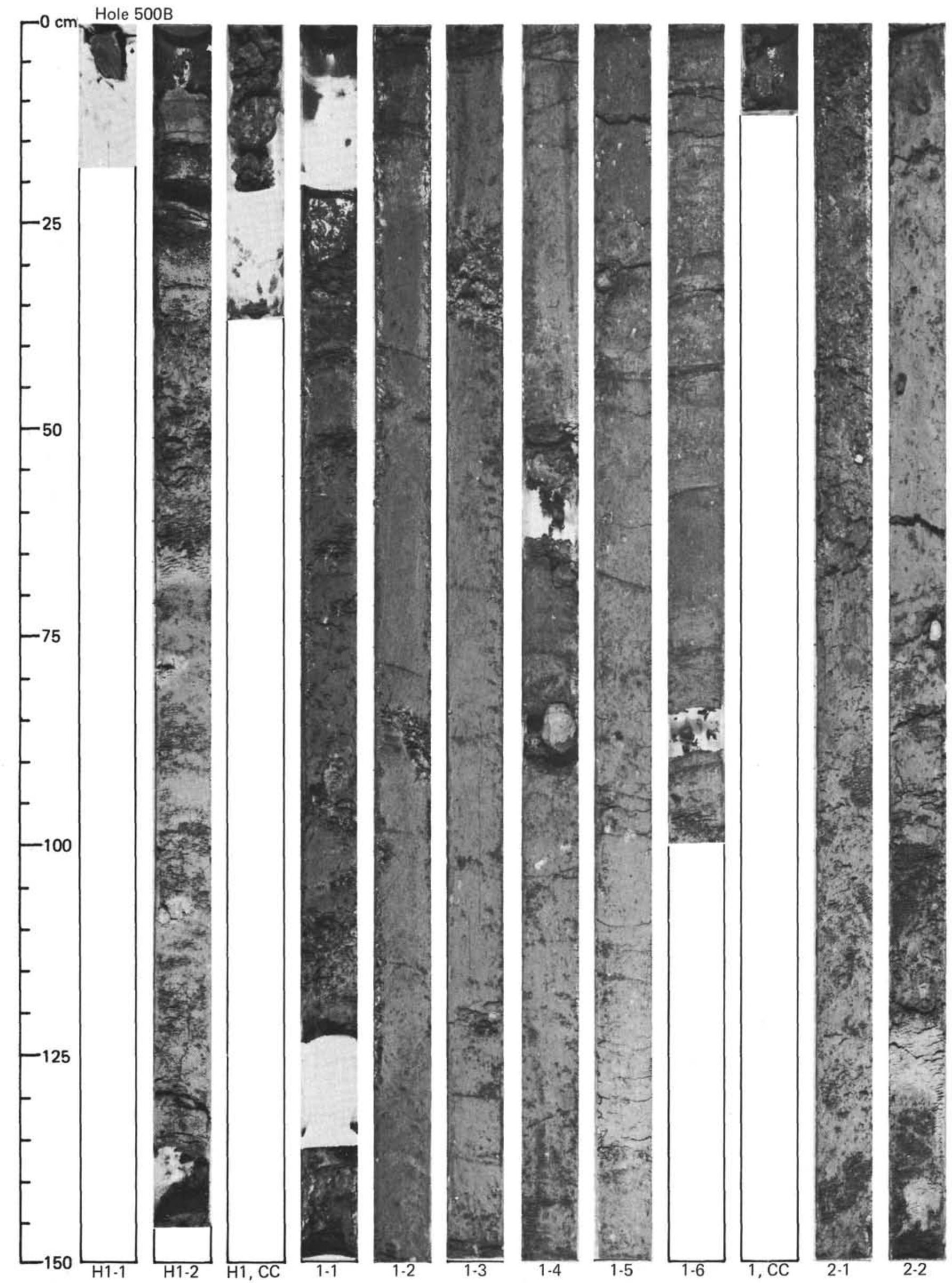




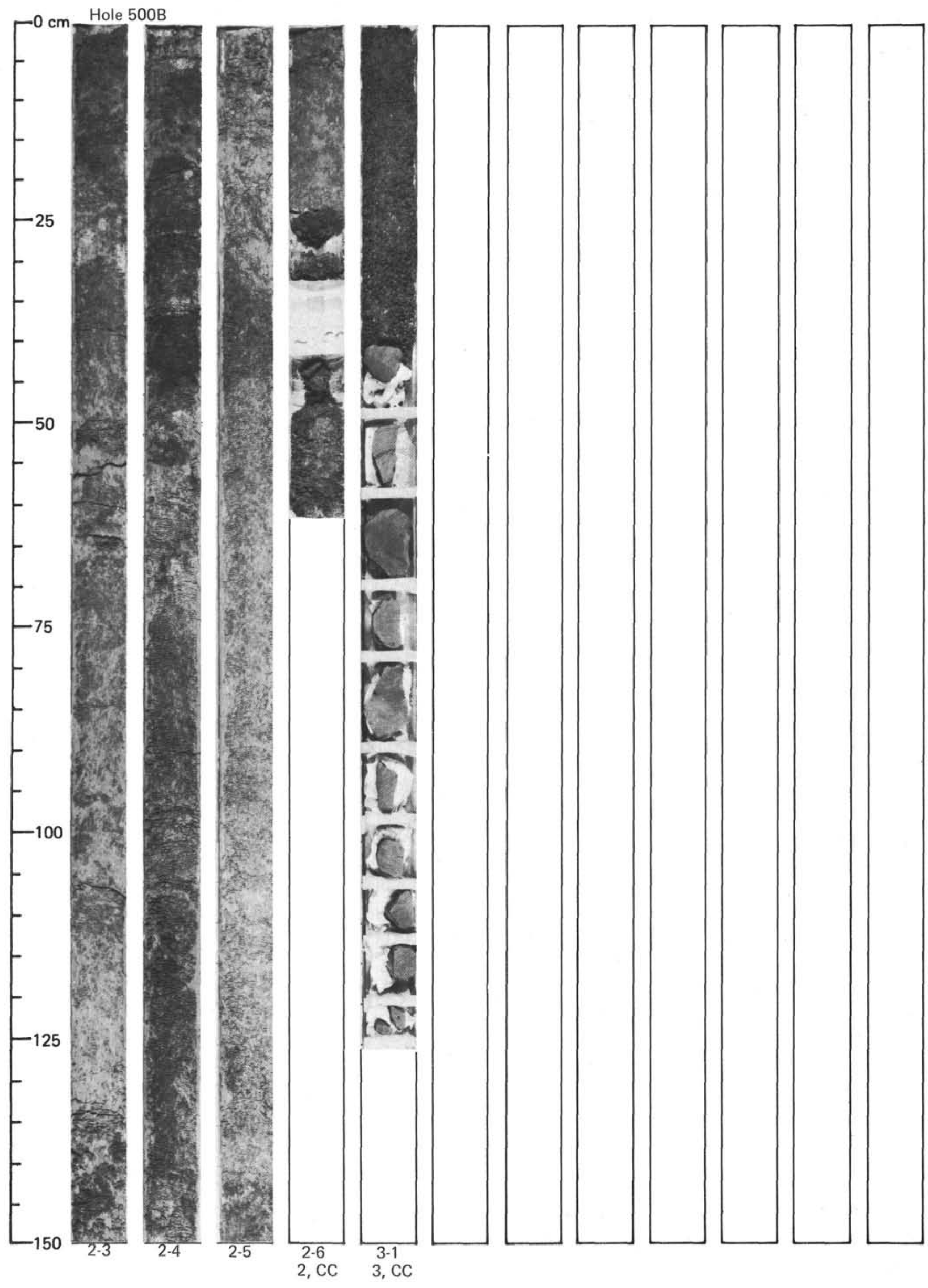

